\title{
Guatteria (ANNONACEAE) do estado do Rio de Janeiro, BrasiL ${ }^{1}$
}

\author{
Adriana Quintella Lobão $o^{2}$ \& Renato de Mello-Silva ${ }^{3}$
}

\begin{abstract}
Resumo
(Guatteria (Annonaceae) do estado do Rio de Janeiro, Brasil) São apresentadas as espécies de Guatteria do estado do Rio de Janeiro. Guateria é o maior gênero das Annonaceae, com cerca de 265 espécies, e apresenta problemas taxonômicos complexos pelas dificuldades de delimitação das espécies e seções, consequência da uniformidade dos caracteres florais e da variabilidade dos caracteres vegetativos. São consideradas 13 espécies: Guatteria burchellii, G. candolleana, G. elliptica, G. ferruginea, G. glabrescens, G. latifolia, G. mexiae, G. nigrescens, G. pohliana, G. pubens, G. reflexa, G. villosissima e G. xylopioides, e 16 nomes são considerados sinônimos. São apresentados chave analítica, descrições das espécies, comentários taxonômicos, informações sobre floração, frutificação, distribuição geográfica, hábitats de ocorrência e ilustrações.
\end{abstract}

Palavras-chave: flora, Floresta Atlântica, sistemática, taxonomia, identificação, distribuição geográfica.

\section{Abstract}

(Guatteria (Annonaceae) of Rio de Janeiro State, Brazil) The species of Guatteria from the state of Rio de Janeiro are presented. The genus is the largest within the Annonaceae, with about 265 species, and is also the most complex one because of the difficulties in delimiting species and sections. These difficulties are due to the similarity of reproductive features between species and huge variation in vegetative features within species. As a result, 13 species of Guatteria are recognized in Rio de Janeiro: Guatteria burchellii, G. candolleana, G. elliptica, G. ferruginea, G. glabrescens, G. latifolia, G. mexiae, G. nigrescens, G. pohliana, G. pubens, G. reflexa, G. villosissima and G.xylopioides, and 16 names are synonymized. Key to the species, descriptions, comments about taxonomy, phenological information and notes on habitats are provided.

Key words: flora, Atlantic Forest, systematic, taxonomy, identification, geographical distribution.

\section{INTRODUÇÃo}

A família Annonaceae constitui a principal família do clado Magnoliales (APGII 2003) e possui cerca de 135 gêneros e 2500 espécies (Chatrou et al. 2004). No Brasil está representada por 26 gêneros, dos quais sete endêmicos, e cerca de 265 espécies e, no estado do Rio de Janeiro, por 12 gêneros e 55 espécies (Maas et al. 2002). Dentre os gêneros, Guatteria é o mais numeroso, com cerca de 280 espécies (Chatrou et al. 2004; Scharf et al. 2005, 2006; Erkens et al. 2006). O gênero apresenta problemas taxonômicos complexos pela dificuldade de delimitação das espécies e seu agrupamento em seções (Fries 1939). Isto é consequiência da uniformidade dos caracteres florais (Heusden 1992) e da variabilidade intraespecífica dos caracteres vegetativos, o que pode ter levado ao estabelecimento de um número superestimado de espécies. Como agravante, há poucas coleções com flores maduras nos herbários e muitos materiais encontram-se duvidosamente identificados. Este trabalho, além de apresentar as Guatteria do estado do Rio de Janeiro, com informações para o reconhecimento e identificação das espécies, provê bases para estudos mais abrangentes e aprofundados do gênero.

\section{Material e Métodos}

Este tratamento inclui exclusivamente as espécies de Guatteria encontradas no estado do Rio de Janeiro, na Região Sudeste do Brasil, entre os paralelos $20^{\circ} 45^{\prime} 56^{\prime \prime} \mathrm{S}$ e $23^{\circ} 22^{\prime} 08^{\prime \prime} \mathrm{S}$ e os meridianos $40^{\circ} 57^{\prime} 23^{\prime \prime} \mathrm{W}$ e $44^{\circ} 53^{\prime} 19^{\prime \prime} \mathrm{W}$ (CIDE 1995). A região fitogeográfica de ocorrência mais comum das Guatteria é a Floresta Ombrófila Densa. O levantamento baseou-se nas coleções dos herbários BHCB, BM, ESA, FCAB, FLOR, GUA, HB, HRCB, K, MBM, OUPR, P, R, RB, RBR, RFA, RFFP, RUSU, SP, SPF, U e UEC (siglas segundo Holmgren et al. 1990). Excursões de coleta foram efetuadas nas principais áreas de ocorrência do grupo. As

Artigo recebido em 11/2006. Aceito para publicação em 07/2007.

${ }^{1}$ Dissertação de mestrado desenvolvida na Universidade de São Paulo com financiamento da FAPESP.

${ }^{2}$ Jardim Botânico do Rio de Janeiro. Rua Pacheco Leão 915. 22460-030, Rio de Janeiro, RJ, Brasil. alobao@ jbrj.gov.br ${ }^{3}$ Departamento de Botânica, Universidade de São Paulo. Cx. Postal 11461. 05422-970 São Paulo, SP, Brasil. 
espécies estão ordenadas em ordem alfabética. A descrição do gênero abrange todas as espécies do táxon; a das espécies está baseada nas coleções do estado ou, às vezes, também em material adicional de outras localidades. Dos materiais examinados foi citado apenas um material por município, em ordem alfabética. As informações sobre floração e frutificação foram obtidas de todos os materiais analisados. Duplicatas não examinadas estão acompanhadas de n.v. (non vidi). A terminologia morfológica está baseada em Font Quer (1965), Radford et al. (1974) e Weberling (1989). As dimensões dos tricomas foram tomadas de material em lâmina com glicerina $50 \%$ e cobertos com lamínula com auxílio de lente graduada adaptada a estereomicroscópio. Na falta das brácteas (quando caducas), as cicatrizes foram contadas. As medidas da pétala jovem foram tomadas desde o momento da abertura do botão floral até a entrada da flor em antese, quando a pétala muda de forma.

\section{Resultados e Discussão}

Guatteria Ruiz \& Pav.

Arbustos ou árvores até $30 \mathrm{~m}$ alt.; raramente lianas. Tricomas 0,2-1 mm compr., simples, eretos ou adpressos, retos ou sinuosos, macios ou rígidos, áureo-ferrugíneos a ferrugíneos. Ramos jovens rígidos ou flexuosos, glabros a densamente cobertos por tricomas. Folhas glabras a densamente cobertas por tricomas; nervação broquidódroma; nervura primária impressa na face adaxial, proeminente na face abaxial; nervuras secundárias arqueadas em direção ao ápice. Flores solitárias ou muitas, terminais, axilares ou caulifloras. Pedicelo articulado acima da base, glabro a densamente coberto por tricomas. Brácteas 2-muitas por flor, abaixo da articulação, persistentes ou caducas. Botões triangular-ovóides ou triangular-obovóides; sépalas 3, 2-12 mm compr., carnosas, livres ou conatas, imbricadas ou valvares, reflexas ou eretas, verdes, esparsa a densamente cobertas por tricomas; pétalas 6(-8), 7-45 mm compr., as do ciclo interno maiores, raramente menores, carnosas, livres ou conatas, imbricadas em ambos os ciclos, esverdeadas, amareladas a creme, esparsa a densamente cobertas por tricomas; face abaxial das pétalas internas geralmente glabra na base. Estames 0,8-2 mm compr., numerosos, linear-cuneados, rígidos, de arranjo espiralado, extrorsos; filetes curtos; conectivo prolongado e expandido sobre a antera, ápice do conectivo papiloso, umbonado ou não, glabro a densamente coberto por tricomas. Carpelos 1,3-4 mm compr., numerosos, esparsa a densamente cobertos por tricomas; estiletes livres; estigmas discóides a obovóides ou orbiculares, subsésseis, glabros a densamente cobertos por tricomas; óvulo 1, anátropo, placentação basal. Frutos apocárpicos; pedicelo $6-65 \times 1-4(-5) \mathrm{mm}$, com fissuras longitudinais, geralmente nigrescente, glabro ou coberto por tricomas; receptáculo 3-14(-17) mm diâm.; estipes 026(-28) mm compr., vináceas a vermelhas; carpídios 2-60(-70), 0,6-2,6 cm compr., baga, indeiscentes, estreitamente elipsóides a obovóides, ovóides ou oblongos. Semente 1 por carpídio, 7-21(-26) ×4-9 mm, ereta, estreita a largamente elipsóide ou largamente obovóide a obovóide, ovóide ou oblonga, circular a largamente elíptica em seção transversal, vinácea ou alaranjada a marrom (Barroso et al. 1978, 1999; Cronquist 1981; Heusden 1992; Setten \& Koek-Noorman 1992).

Guatteria é um gênero monofilético (Doyle \& Le Thomas 1996; He et al. 1999; Pirie et al. 2005, Erkens 2007) e suas espécies são encontradas desde o sudeste mexicano até a Bolívia e sul do Brasil, muitas preferencialmente perto de rios ou locais úmidos e raramente acima de $1000 \mathrm{~m}$ de altitude. Cerca da metade das espécies ocorre na Amazônia (Barringer 1984) e outro centro de diversidade é a mata atlântica do Brasil, da Bahia a Santa Catarina, que é o limite austral das espécies.

No estado do Rio de Janeiro são encontradas 13 espécies: Guatteria burchellii, G. candolleana, G. elliptica, G. ferruginea, G. glabrescens, G. latifolia, G. mexiae, G. nigrescens, G. pohliana, G. pubens, $G$. reflexa, G. villosissima e G. xylopioides. 


\section{Chave para as espécies de Guatteria do estado do Rio de Janeiro}

1. Ápice do conectivo com umbo central

3. G. elliptica

1'. Ápice do conectivo plano.

2. Botão floral com sépalas conatas em toda a extensão; brácteas 2 por flor, caducas.

3. Botões florais densamente cobertos por tricomas, com sépalas com linha de deiscência; lâmina foliar densamente coberta por tricomas na face abaxial; margem in sicco freqüentemente revoluta; pedicelo $1,5-2(-3,5) \mathrm{cm}$ compr. 12. G. villosissima

3 '. Botões florais glabros a esparsamente cobertos por tricomas, com sépalas sem linha de deiscência; lâmina foliar glabra a esparsamente coberta por tricomas na face abaxial; margem in sicco às vezes levemente ondulada ou ondulada; pedicelo 1,8-4,5(-6) cm compr.

4. Botões florais ca. $10 \times 12 \mathrm{~mm}$; frutos com receptáculo 8-10 $\times 15-17 \mathrm{~mm}$; lâmina foliar 10-17(-19) $\times 4-6,5(-7) \mathrm{cm}$

6. G. latifolia

4'. Botões florais ca. $5 \times 7 \mathrm{~mm}$; frutos com receptáculo ca. $6 \times 6 \mathrm{~mm}$; lâmina foliar $4,5-10(-12) \times 1,5-2,5(-3,5) \mathrm{cm}$ 9. G. pohliana

2'. Botão floral com sépalas livres ou conatas na metade proximal ou, raramente, conatas em toda a extensão e então brácteas 1-4 por flor, persistentes.

5. Pétalas maduras $13-14 \times 5-6 \mathrm{~mm}$ 10. G. pubens

5'. Pétalas maduras $16-30 \times 5-20 \mathrm{~mm}$.

6. Pétalas com ápice agudo a longo acuminado.

7. Lâmina foliar coriácea; margem freqüentemente revoluta; ápice agudo .... 11. G reflexa

7'. Lâmina foliar cartácea; margem plana ou às vezes levemente ondulada; ápice acuminado a longo acuminado.

8. Lâmina foliar com nervuras secundárias fortemente impressas na face adaxial; margem plana, in sicco às vezes levemente ondulada; $10-19,5(-21)$ $\times 3,5-7 \mathrm{~cm}$; brácteas caducas; sépalas reflexas; carpelo ca. 2,5 mm compr.; estipe $15-25 \mathrm{~mm}$ compr.; carpídios ca. $10 \times 7 \mathrm{~mm}$........... 8. G. nigrescens

8 '. Lâmina foliar com nervuras secundárias proeminentes em ambas as faces; margem plana; $8-14(-18) \times 2-5 \mathrm{~cm}$; brácteas freqüentemente persistentes; sépalas eretas; carpelo ca. $2 \mathrm{~mm}$ compr.; estipe $5-15 \mathrm{~mm}$ compr.; carpídios $7-10 \times 5 \mathrm{~mm}$

2. G. candolleana

6'. Pétalas com ápice obtuso.

9. Lâmina foliar 17-34,5 $(-37,5) \times 6-10(-12) \mathrm{cm}$.

10. Flores $2-25$, caulinares, raramente axilares

1. G. burchellii

10 . Flor 1, sempre axilar

4. G. ferruginea

9'. Lâmina foliar 5,5-17×1,7-6 cm.

11. Lâmina foliar com base decurrente; ápice acuminado; glabra a esparsamente coberta por tricomas adpressos na face abaxial; botões florais esparsamente cobertos por tricomas sinuosos 5. G. glabrescens

11'.Lâmina foliar com base e ápice agudos; esparsa a densamente coberta por tricomas adpressos ou eretos na face abaxial; botões florais densamente cobertos por tricomas sinuosos ou retos.

12. Lâmina foliar densamente coberta por tricomas eretos na face abaxial, cartácea a levemente coriácea; botões florais freqüentemente com sépalas livres, raramente conatas em toda extensão quando jovem; brácteas 1-4 por flor, persistentes

7. G. mexiae

12'.Lâmina foliar esparsamente coberta por tricomas adpressos na face abaxial, cartácea; botões florais com sépalas conatas na metade proximal; brácteas 2 por flor, caducas 13. G. xylopioides 
1. Guatteria burchellii R.E.Fr., Acta Horti Berg. 12(3): 398. 1939. Typus: BRASIL. RIODE JANEIRO: Magé, Frechal to Magé, 25.II.1826, fl., W. J. Burchell 2698 (holotypus, K; isotypus, P; foto, SPF, U).

Fig. $1 \mathrm{c}-\mathrm{h}$

Árvores 3-10 m alt. Tricomas ferrugíneos, $0,6-0,8 \mathrm{~mm}$ compr., macios. Gemas, folhas jovens e ramos jovens densamente cobertas por tricomas eretos, retos. Pecíolo nigrescente, 6-12 cm compr., canaliculado, com fissuras transversais, glabro a esparsamente coberto por tricomas eretos, retos. Lâmina foliar verde, in sicco marrom, $22-30 \times 6-10 \mathrm{~cm}$, cartácea, estreitamente elíptica a estreitamente obovada, glabra a esparsamente coberta por tricomas eretos e retos na face adaxial, esparsamente coberta por tricomas eretos, retos, na abaxial; base obtusa a curto-decurrente; margem plana; ápice acuminado, acúmen ca. $1 \mathrm{~cm}$ compr; nervura primária glabra na face adaxial, esparsamente coberta por tricomas eretos, retos, na abaxial; nervuras secundárias 17-20 pares, impressas na face adaxial, proeminentes na abaxial, formando ângulo de $60-75^{\circ} \mathrm{com}$ a nervura primária. Flores 2-25, caulinares, raramente axilares. Pedicelo $3,5-6 \mathrm{~cm}$ compr., da base à articulação $2-4 \mathrm{~mm}$ compr., esparsamente coberto por tricomas eretos, retos. Bráctea 1, caduca. Botões florais triangularovóides, densamente cobertos por tricomas eretos, sinuosos; com sépalas livres, valvares, eretas. Sépalas verdes, $5-10 \times 7 \mathrm{~mm}$, triangulares, livres, valvares, eretas, glabrescentes na face adaxial, esparsa a densamente cobertas por tricomas eretos, sinuosos na abaxial, margem plana. Pétalas ovadas a elípticas, densamente cobertas por tricomas eretos, sinuosos, base glabra na face adaxial, ápice obtuso; pétalas jovens esverdeadas, 13-20 × 6-12 mm; pétalas maduras, amarelas, ca. $20 \times 10-12 \mathrm{~mm}$. Estames ca. $2 \mathrm{~mm}$ compr., ápice do conectivo plano. Carpelos nigrescentes, ca. $2 \mathrm{~mm}$ compr., cobertos por tricomas eretos na base; estigma papiloso. Frutos com receptáculo largamente depresso-obovóide; cálice não persistente, estipes in sicco nigrescentes, ca. $2,5 \mathrm{~cm}$ compr., glabros; carpídios in sicco nigrescentes, ca. $12 \times 7 \mathrm{~mm}$, elipsóides, glabros, curto-apiculados. Semente in sicco marromclaro a escuro, ca. $1 \mathrm{~cm}$ compr., elipsóide.
Material selecionado: Cachoeiras de Macacu, Reserva Ecológica Estadual do Paraíso, $22^{\circ} 27^{\prime} / 22^{\circ} 32^{\prime}$ 'S $42^{\circ} 50^{\prime} /$ $42^{\circ} 56^{\prime} \mathrm{W}$, elev. 100-160 m., fl. e fr., R. R. Guedes 2224 (RB, U); Guapimirim, Parque Nacional da Serra dos Órgãos, sub-sede, próximo ao Museu von Martius, 5.X.1980, fr., H. C. Lima \& M. P. M. Lima 1551 (RB, U); Magé, área do Centro de Primatologia do Rio de Janeiro, elev. 200 m, 17.X.1984, fr., H. C. Lima 2210 (K, RB); Nova Iguaçu, 12.XI.2001, fl., H. C. Lima 5887 (RB); Teresópolis, Serra do Órgãos, Barreiras, 1.I.1968, fl., E. Pereira 10656 (HB, K).

Guatteria burchellii é caracterizada pelas inflorescências caulinares e pedicelo com 3,5 a $6 \mathrm{~cm}$ compr. Em geral os pedicelos e, conseqüentemente, a entrada da câmara de polinização da flor ficam paralelos ao solo, diferentemente da maioria das espécies onde a flor é pendente. É similar a G. ferruginea da qual difere porque, além das flores solitárias e axilares, $G$. ferruginea apresenta a face abaxial das folhas densamente coberta por tricomas ferrugíneos e pedicelo com cerca de $2 \mathrm{~cm}$ compr. Guatteria burchellii tem distribuição disjunta, com populações na floresta ombrófila ao norte da Baía da Guanabara e no sul da Bahia. No estado do Rioé frequiente nas florestas submontanas e há uma grande população ao longo do rio Paquequer. Não foi encontrada acima de $900 \mathrm{~m}$. Floresce de setembro a julho e frutifica de julho a fevereiro. Quando florida, é bastante vistosa em virtude do número de flores e da caulifloria.

2. Guatteria candolleana Schltdl., Linnaea 9: 325. 1835. Typus: BRASIL. RIO DE JANEIRO: Sumidouro, s.d., F. Sellow 5442 p.p. (holotypus, B n.v.; isotypus, BR n.v., K, foto, SPF).

Fig. $2 \mathrm{a}-\mathrm{g}$

Cananga candolleana (Schltdl.) Warm., Vidensk. Meddel. Dansk Naturhist. Foren. Kjobenhavn 1873: 145. 1873.

Guatteria psilopus Mart. in Mart. \& Eichler, Fl. bras. 13(1): 27, tab. 7, fig. 1. 1841. Typus: BRASIL. RIO DE JANEIRO: Teresópolis, Serra dos Órgãos, VI.1834, fl., B. Luschnath s.n. (holotypus, BR n.v.; foto, U). Syn. nov. Guatteria hookeri A.St.-Hil \& Tul., Ann. Sci. Nat., Bot. sér. 2. 17: 132. 1842. Typus: BRASIL. RIO DE JANEIRO: Teresópolis, banks of the river Paquequer, in the Organ mountains, 


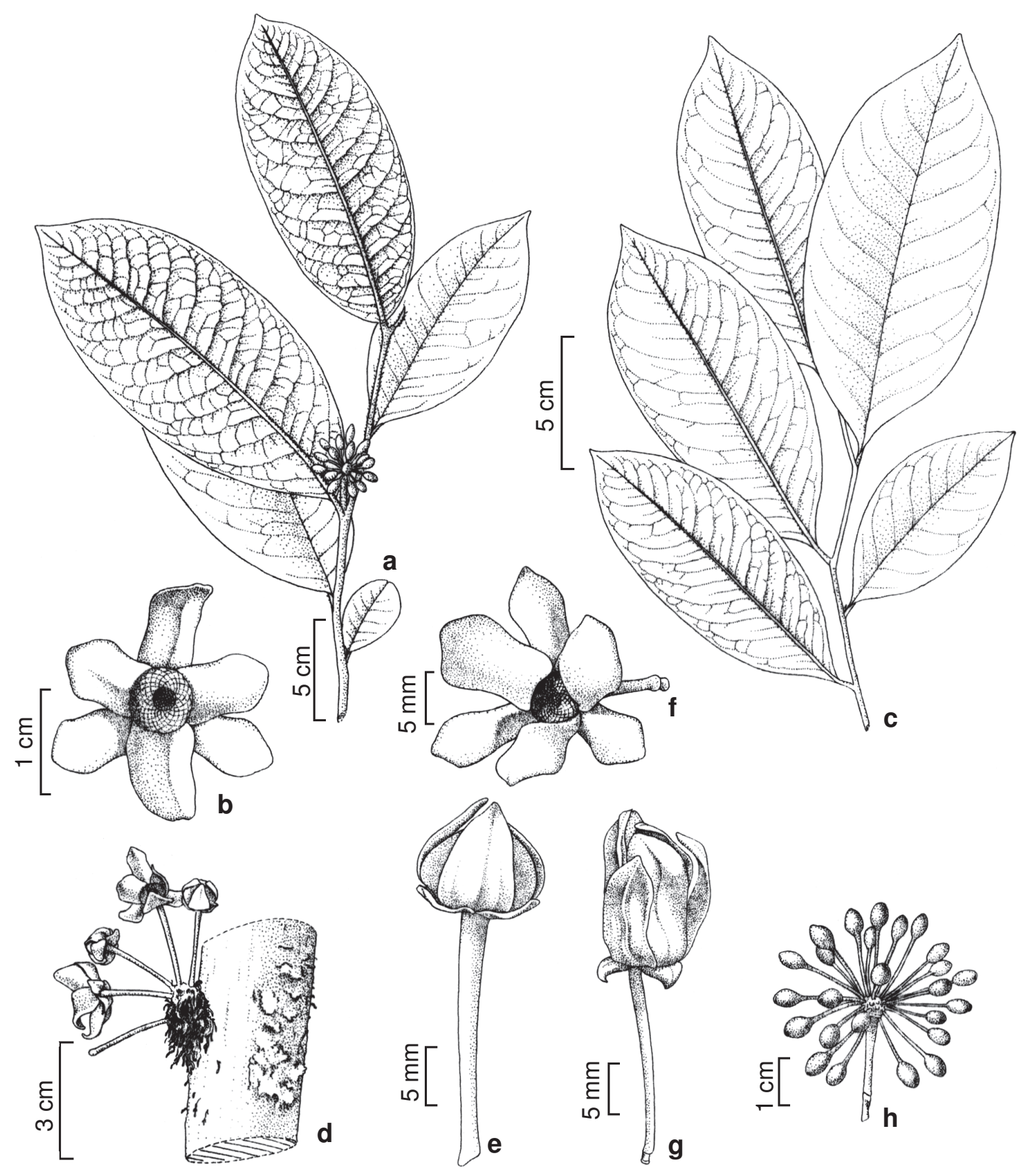

Figura 1 - a-b. Guatteria ferruginea - a. ramo com fruto; b. flor jovem. c-h. G. burchellii. - c. ramo; d. inflorescência cauliflora; e. botão floral; f. flor entrando em antese; g. flor madura; h. fruto. (a-b Lobão 650; c-f Duarte s.n. (RB 65280); g-h Lobão 643) 
III.1837, fl., G. Gardner 306 p.p. (holotypus, $\mathrm{P}$; isotypi, $\mathrm{BM}$ n.v., E n.v., F n.v., G n.v., LZ n.v., $\mathrm{K}, \mathrm{P}, \mathrm{S} n . v$; foto, SPF, U). Syn. nov.

Guatteria hilariana var. pallescens R.E.Fr., Kongl. Svenska Vetensk. Acad. Handl. n.s. 34(5): 15. 1900. Typus: BRASIL. RIO DE JANEIRO: Rio de Janeiro, Jacarepaguá, 29.XII.1869, fl., A. F. M. Glaziou 3855 (syntypi, B n.v, C, n.v, K, P; foto, SPF, U).

Guatteria penduliflora R.E.Fr., Acta Horti Berg. 12(3): 341, tab. 15. 1939. Typus: BRASIL. RIO DE JANEIRO: Sem localidade, 1860, fl., $F$. F. Allemão \& Cysneiro s.n. (holotypus, G n.v., foto, SP). Syn. nov.

Arbustos ou árvores 1,5-9 m alt. Tricomas áureo-ferrugíneos, 0,2-0,5 mm compr. Gemas e folhas jovens glabras a densamente cobertas por tricomas adpressos ou eretos, retos; ramos jovens rígidos, densamente cobertos por tricomas adpressos ou eretos, retos, ramos adultos glabros a esparsamente cobertos por tricomas adpressos ou eretos, retos. Pecíolo nigrescente, 3-7 mm compr., levemente canaliculado, com fissuras transversais, glabro a densamente coberto por tricomas adpressos, retos. Lâmina foliar verde, in sicco marrom, 8-14(-18) × 2-5 cm, cartácea, estreitamente elíptica, glabra na face adaxial; glabra a densamente coberta por tricomas adpressos ou eretos, retos na abaxial; base arredondada a levemente decurrente; margem plana; ápice longo-acuminado, acúmen 1-2 cm compr.; nervura primária glabra a esparsamente coberta por tricomas adpressos na face adaxial, glabra a densamente coberta por tricomas na face abaxial; nervuras secundárias ca. 10 pares, proeminentes em ambas as faces, formando ângulo de $55-75^{\circ}$ com a nervura primária. Flor 1, axilar. Pedicelo nigrescente, 2-6,5 cm compr., da base à articulação 1-3,5 cm compr., delgado, esparsa a densamente coberto por tricomas adpressos ou eretos, retos. Brácteas 2-3 por flor, freqüentemente persistentes, densamente cobertas por tricomas adpressos, retos, na face abaxial. Botões florais triangular-ovóides, esparsa a densamente cobertos por tricomas eretos, sinuosos, com sépalas livres, valvares, eretas. Sépalas verdes, in sicco nigrescentes,
5-7 $\times 7 \mathrm{~mm}$, triangulares, livres, valvares, eretas, densamente cobertas por tricomas eretos, sinuosos, na face abaxial, glabras a esparsamente cobertas por tricomas eretos, sinuosos, na adaxial, margem plana. Pétalas estreitamente elípticas, densamente cobertas por tricomas eretos, sinuosos, na face abaxial, glabras na base da face adaxial, ápice agudo. Pétalas jovens esverdeadas, $10-15 \times 5-8 \mathrm{~mm}$; pétalas maduras amareladas, $18-22 \times 5-8 \mathrm{~mm}$. Estames ca. $2 \mathrm{~mm}$ compr., ápice do conectivo plano. Carpelos ca. $2 \mathrm{~mm}$ compr., na base densamente cobertos por tricomas eretos, retos; estigma nigrescente, papiloso. Frutos com receptáculo obovóide; cálice não persistente; estipes verde-vináceos, in sicco nigrescentes, 5-15 mm compr., glabros; carpídios verdevináceos, in sicco nigrescentes, 16-26(-50), 7$10 \times 5$ mm, elipsóides, glabros, curto-apiculados. Semente alaranjada a vinácea, in sicco marromclaro a marrom-escuro, 5-10×5 mm, elipsóide. Material selecionado: Guapimirim, fazendas Consorciadas, 18.II.2001, fl., F. M. B. Pereira 11/74 (RFA); Itatiaia, Parque Nacional do Itatiaia, Lago Azul, 8.III.1947, fl. e fr., P. Occhioni s.n. (RFA 4208); Magé, VI.1975, fl., P. Occhioni 7398 (RFA); Niterói, Praia Grande, 18.II.1870, fl., A. F. M. Glaziou 3857 (P); Nova Friburgo, Muri, Reserva Ecológica Municipal de Macaé de Cima, estrada para o sítio Sophonites, 2200'S 4203'W, elev. 1000 m, 28.XII.1986, fl. e fr., S. V. A. Pessoa et al. 144 (RB); Petrópolis, caminho do Capoeirão, elev. 800 m, 26.IX.1977, fr., G. Martinelli 3064 (RB, U); ascent of hight mountant on the NW side and along the aqueduct, I.1826, fl. e fr., W. $J$. Burchell 1839 (BR); Sapucaia, Terceiro Distrito, fazenda Selo Verde, $22^{\circ} 05^{\prime} 02^{\prime \prime} S 42^{\circ} 50^{\prime} 36$ "W, X.2000, fr., F. M. B. Pereira 28/44 (RFA); Silva Jardim, Reserva Biológica de Poço das Antas, trilha para faz. Portuense, próx. Entrada do Cajueiro, 15.III.1994, fl. e fr., D. S. Farias 164 (RB); Teresópolis, Parque Nacional da Serra dos Órgãos, estrada principal logo após o mirante Beija Flor, 17.V.2005, fr., A. Q. Lobão et al. 702 (RB, SPF), Varre-Sai, 11.XI.1941, fl., E. Pereira 18(RB).

Guatteria candolleana caracteriza-se pelos ramos jovens densamente cobertos por tricomas longos e ferrugíneos; folhas com acúmen de 1 a $2 \mathrm{~cm}$ compr., pedicelo floral e do fruto com ca. $5 \mathrm{~cm}$ compr.e pétalas lanceoladas comápice agudo. Em geral as pétalas são estreitamente triangulares conferindo à flor jovem um aspecto estrelado. 


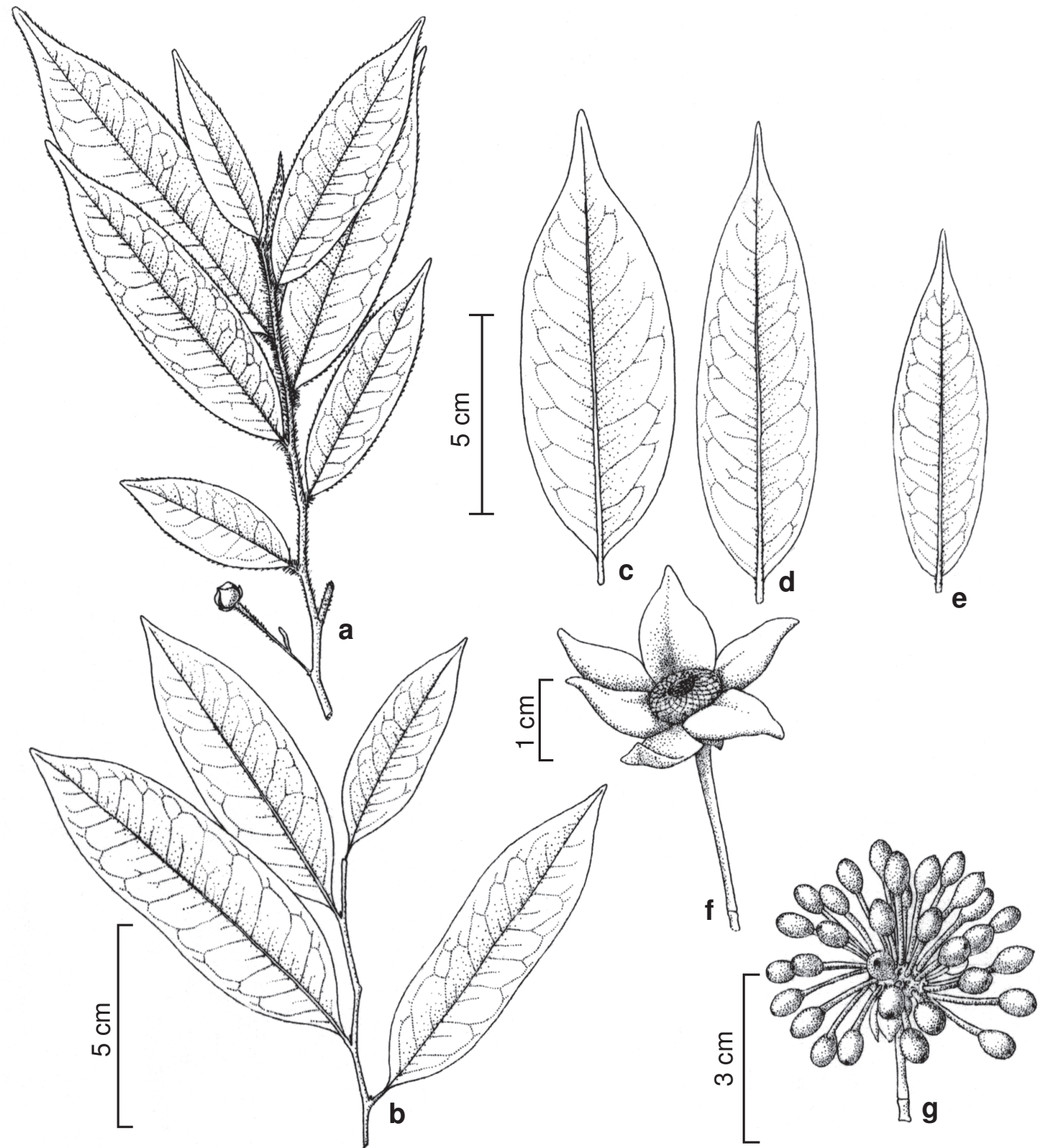

Figura 2 - a-g. Guatteria candolleana - a. ramo coberto por tricomas; b. ramo glabro; c-e. folhas; f. flor jovem; g. fruto. (a, f, g Nadruz 572; b Sucre 2415; c Pereira 18; d Pereira 454)

Todas as características são comuns às espécies e variedades aqui sinonimizadas. $G$. psilopus seria afim de G. candolleana (Martius 1841), mas as difenças consideradas são insuficientes para a separação destas espécies. G. hookeri seria semelhante a G. psilopus (Fries 1939) mas Gardner 306 p.p. (typus de G. hookeri) caracteriza-se por estados de caráter que se enquadram na variação de $G$. candolleana. No material em $\mathrm{K}$ a variação dos diversos caracteres mostra claramente as semelhanças de G. hookeri com G. psilopus e G. candolleana. O tipo de G. candolleana é composto de dois materiais diferentes. Um possui folhas com base arredondada e face adaxial glabra, pedicelo delgado e levemente pêndulo e sépalas com face abaxial glabra. $O$ outro possui folhas com base aguda, face adaxial coberta por tricomas, pedicelos rígidos e eretos e sépalas lanosas. O primeiro foi classificado como $G$. candolleana e o segundo como G. mexiae (Fries 1939). Com exceção da base, as diferenças 
apontadas por Fries (1939) sustentam as duas espécies. Autores que usaram a base da lâmina foliar para caracterizar G. candolleana (Schlechtendal 1834; Fries 1939; Maas et al. 2002) não consideraram a variação desta característica. Geralmente as folhas jovens apresentam base arredondada e as maduras, base aguda. Também o indumento é variável. Exemplares da restinga de Mauá, Rio de Janeiro, apresentam as gemas e as folhas com face abaxial esparsamente coberta por tricomas. Em Macaé de Cima e Teresópolis, há representantes com ramos e folhas glabros e outros com ramos e face abaxial das folhas densamente cobertas por tricomas. Guatteria candolleana assemelha-se a $G$. nigrescens, mas esta possui nervuras secundárias fortemente impressas na face adaxial, sépalas reflexas e estipes de 15 a 25 mm compr. Mas ambas variam em muitas características e talvez possam vir a ser sinonimizadas.

Guatteria candolleana é encontrada em Minas Gerais, São Paulo e, no Rio de Janeiro, na floresta submontana e de terras baixas. Floresce e frutifica durante quase todo o ano, mas a maioria das coleções foi feita em meses quentes e chuvosos.

3. Guatteria elliptica R.E.Fr., Acta Horti Berg. 12(3): 445, fig. 19c, d. 1939. Typus: BRASIL. RIO DE JANEIRO: São Fidelis, C. (cultivada?), 18.II.1876, fl., A. F. M. Glaziou 9605 (holotypus, C n.v.; isotypi, K, P 2 exsicatas; foto, SPF, U).

Arbustos ou árvores. Gemas e folhas jovens densamente cobertas por tricomas ferrugíneos; ramos jovens rígidos, densamente cobertos por tricomas ferrugíneos. Pecíolo 4-5 mm compr., canaliculado, densamente coberto por tricomas eretos. Lâmina foliar verde, in sicco atrofuscas, 15-20 ×5-6 cm, levemente coriácea, estreitamente elíptica, esparsamente coberta por tricomas na face adaxial; densamente coberta por tricomas na abaxial; base arredondada a levemente decurrente; margem plana; ápice agudo; nervura primária esparsamente coberta por tricomas adpressos, retos, na face adaxial, densamente coberta por tricomas adpressos, retos, na face abaxial; nervuras secundárias $12-15$ pares, proeminentes na face abaxial, formando ângulo de $60-70^{\circ} \mathrm{com}$ a nervura primária. Flor 1, axilar. Pedicelo 1$1,5 \mathrm{~cm}$ compr., da base à articulação $2-3 \mathrm{~cm}$ compr., rígido, densamente coberto por tricomas adpressos ou eretos, retos. Brácteas caducas. Botões florais não vistos. Sépalas verdes, in sicco nigrescentes, 5-6 × 5-6 mm, largamente triangulares, livres, valvares, reflexas, densamente cobertas por tricomas na face abaxial, glabras na face adaxial, margem plana. Pétalas elípticas, densamente cobertas por tricomas eretos, sinuosos na face abaxial, glabras na base da face adaxial, ápice obtuso; pétalas jovens 10-14×7-8 mm. Estames 1,51,8 mm compr., ápice do conectivo com umbo central. Carpelos esparsamente cobertos por tricomas eretos, retos. Frutos não vistos.

Guatteria elliptica difere das espécies do Rio de Janeiro pela presença de umbo no conectivo das anteras. Somente o tipo é conhecido e muito provavelmente não ocorre no Rio de Janeiro, pois pertence ao grupo essencialmente amazônico de Guatteria sect. Tylodiscus. Spruce 896 (parátipo de G. umbonata R.E.Fr.) proveniente de Santarém, Pará, é provavelmente $G$. elliptica e talvez ambas sejam a mesma espécie. Muitas outras coletas de Glaziou, especialmente de Melastomataceae, anotadas como do Rio de Janeiro, seriam provenientes da Amazônia (Wurdack 1970). Amorim (2003) assinala que Glaziou 9678?, com numeração próxima ao do tipo de G. elliptica, deve ser originário de Santarém, Pará, apesar de registrado como do Rio de Janeiro. Guatteria elliptica ocorreria em São Fidélis, no norte fluminense, área de floresta de terras baixas atualmente bastante devastada. Coletada em flor em fevereiro.

4. Guatteria ferruginea A.St.-Hil., Fl. Bras. merid. 1: 38. 1825. Typus: BRASIL. RIO DE JANEIRO: Nova Iguaçu, Capueiras près Aguassu, XII.1816, fl., A. F. C. P. Saint-Hilaire 2 (holotypus, $\mathrm{P}$; isotypus, $\mathrm{P}, \mathrm{S}$ n.v.).

Fig. $1 \mathrm{a}-\mathrm{b}$

Guatteria glazioviana R.E.Fr., Kongl. Svenska Vetenskapsakad. Handl. 34(5): 19, tab. 2, fig. 1, 2. 1900. Typus: BRASIL. RIO DE JANEIRO: Nova Friburgo, Alto da Boa Vista de Nova Friburgo, 23.I.1874, st., A. F. M. Glaziou 6856 (syntypi, B n.v., BR n.v., C n.v., K, P, S n.v.; foto, SPF). 
Árvores 2-8 m alt. Tricomas ferrugíneos, 0,6-0,8 mm compr. Gemas e ramos adultos e folhas jovens densamente cobertas por tricomas eretos, retos; ramos jovens rígidos, densamente cobertos por tricomas eretos, retos. Pecíolo nigrescente, 6-12 mm compr., canaliculado, com fissuras transversais, glabro a esparsamente coberto por tricomas eretos, retos. Lâmina foliar verde, in sicco marrom, 17-34,5 (-37,5) × 6,5$10(-12) \mathrm{cm}$, cartácea, elíptica a estreitamente obovada; glabra a esparsamente coberta por tricomas na face adaxial, densamente coberta por tricomas eretos, retos na abaxial; base obtusa a curto-decurrente; margem plana; ápice acuminado, acúmen 1-2 cm compr.; nervura primária glabra na face adaxial, coberta por tricomas eretos, retos na abaxial; nervuras secundárias 17-20 pares, impressas na face adaxial, proeminentes na abaxial, formando ângulo de $60-75^{\circ} \mathrm{com}$ a nervura primária. Flor 1 , axilar. Pedicelo 1,5-3,5 cm compr., da base à articulação 3-5(-10) mm compr., densamente coberto por tricomas eretos, retos. Bráctea 1, cedo caduca. Botões florais triangular-ovóides, densamente cobertos por tricomas eretos, sinuosos, com sépalas livres, valvares, eretas. Sépalas verdes, 5-10 $\times 7 \mathrm{~mm}$, triangulares, livres, valvares, eretas, glabrescentes na face adaxial, densamente cobertas por tricomas eretos, sinuosos, na abaxial, margem plana. Pétalas ovadas a elípticas, densamente cobertas por tricomas eretos, sinuosos, base glabra na face adaxial, ápice obtuso; pétalas jovens esverdeadas, 13-20 ×6 $12 \mathrm{~mm}$; pétalas maduras amarelas, ca. $20 \times 10$ $12 \mathrm{~mm}$. Estames ca. $2 \mathrm{~mm}$ compr., ápice do conectivo plano. Carpelos ca. $2 \mathrm{~mm}$ compr., cobertos por tricomas eretos, retos na base, ferrugíneos; estigma papiloso, nigrescente. Frutos com receptáculo largamente depresso-obovóide; cálice não persistente; estipes in sicco nigrescentes, ca. $2,5 \mathrm{~cm}$ compr., glabras; carpídios in sicco nigrescentes, ca. $12 \times 7 \mathrm{~mm}$, elipsóides, glabros, curto apiculados. Semente marrom, ca. $1 \mathrm{~cm}$ compr., elipsóide.

Material selecionado: Barra do Piraí, Ribeirão das Lages, 5.VII.1983, fl. efr., A. L. Peixoto \& O. L. Peixoto 1869 (RBR, UEC); Duque de Caxias, Reserva da Petrobrás, refinaria Duque de Caxias, Pedra Branca, margem do rio Pedra Branca, 5.VIII.1997, fl. e fr., J. M.
A. Braga 4326 (RB, USU); Macaé, fazenda Crubixaes, próximo ao Pico do Frade, elev. 600-650 m, 6.II.1985, fl., C. Farney et al. 548 (F n.v., RB, U); Nova Friburgo, V Distrito, Rio Bonito de Cima, sítio São Jerônymo, elev. 860 m, 8.I.1995, fl., C. E. B. Pereira 59 (GUA); Paracambi, Floresta, $\mathrm{km} 9$, fazenda do Sr. Antônio de Moura, 8.VII.1987, fl., J. P. P. Carauta et al. 5453 (GUA); Petrópolis, Serra de Petrópolis, sítio do Astrogildo, X.1964, st., A. P. Duarte 8469 (RB); Santa Maria Madalena, Serra do Rifa, foz do Lugão, próximo ao rio Imbé, 17.III.1981, fr., D. S. Solza et al. 341 (GUA); Rio de Janeiro, Jacarepaguá, represa do Camorim, 16.VII.1969, fl., D. Sucre 5648 (RB); Silva Jardim, Reserva Biológica de Poço das Antas, próximo a Aldeia Velha, 25.X.1979, fr., D. S. D. Araujo 3398 (GUA).

Guatteria ferruginea caracteriza-se pelas folhas grandes com no mínimo $17 \mathrm{~cm}$ compr. e $6,5 \mathrm{~cm}$ larg., com face abaxial coberta por tricomas ferrugíneos, pedicelos com cerca de 2,5 cm compr. e flores solitárias. Assemelha-se a G. burchellii (vide acima) e também a G. pogonopus Mart., ambas com folhas que chegam a $30 \mathrm{~cm}$ compr., fato raro entre as Guatteria extra-amazônicas, e diversas partes densamente cobertas por tricomas ferrugíneos. Tais características variam pouco em G. ferruginea e G. pogonopus e o reconhecimento das duas espécies é problemático.

Guattteria ferruginea é encontrada no Amapá, Amazonas, Bahia e, no Rio de Janeiro, em floresta de terras baixas e submontana. Foi coletada em flor de novembro a fevereiro, junho a outubro e em fruto em março, de junho a agosto e dezembro.

5. Guatteria glabrescens R.E.Fr., Acta Horti Berg. 12(3): 311, tab. 5. 1939. Typus: BRASIL. RIO DE JANEIRO: Petrópolis, silva loco Fabrica Alliança, 11.I.1922, fl., J. G. Kuhlmann s.n. (holotypus, S n.v.; isotypus, F n.v., RB 4483).

Fig. 3 a-f

Guatteria salicifolia R.E.Fr., Acta Horti Berg. 12(3): 316, fig. 3d, tab. 10. 1939. Typus: BRASIL. RIO DE JANEIRO: Rio de Janeiro, Tijuca, 21.XII.1874, fl., A. F. M. Glaziou 7508 (holotypus, B n.v.; isotypi, C n.v., K, MG n.v., P; foto, SPF, U). Syn. nov.

Guatteria salicifolia var. erosa R.E.Fr. Acta Horti Berg. 12(3): 316. 1939. Typus: BRASIL. PARANÁ: Jacareí, 1914, fl., P. K. H. Dusén s.n. (holotypus, S n.v.). Syn. nov. 
Árvores (3-)5-25 m alt. Tricomas áureoferrugíneos, 0,2-0,5 mm compr. Gemas, folhas jovens e ramos jovens glabros a cobertos por tricomas adpressos, retos; ramos adultos glabros. Pecíolo nigrescente, 3-10 mm compr., leve a profundamente canaliculado, glabro a esparsamente coberto por tricomas adpressos, retos. Lâmina foliar verde, in sicco levemente azulada, 8-15(-17) × 1,7-4,5 cm, cartácea a membranácea, estreitamente elíptica a oblanceolada, glabra na face adaxial, glabra a esparsamente coberta por tricomas adpressos, retos, na abaxial; base decurrente; margem às vezes levemente ondulada, ápice acuminado, acúmen ca. $6 \mathrm{~mm}$ compr.; nervura primária glabra na face adaxial, coberta por tricomas adpressos, retos na abaxial; nervuras secundárias 15-20 pares, proeminentes em ambas as faces, formando ângulo de $70-90^{\circ} \mathrm{com}$ a nervura primária. Flor 1 , axilar. Pedicelo nigrescente, 1,7-4 cm compr., da base à articulação $0,5-1 \mathrm{~cm}$ compr., glabro a densamente coberto por tricomas adpressos, retos. Brácteas 2 por flor, caducas. Botões florais triangular-ovóides, esparsamente cobertos por tricomas eretos, sinuosos, sépalas livres, valvares, reflexas. Sépalas verdes, in sicco nigrescentes, largamente triangulares, livres, valvares, reflexas, cobertas por tricomas eretos, sinuosos em ambas as faces, margem plana, sépalas jovens $2-5 \times$ $3 \mathrm{~mm}$, as maduras ca. $6 \times 6 \mathrm{~mm}$. Pétalas ovadas a elípticas, cobertas por tricomas eretos, sinuosos em ambas as faces, ápice obtuso; pétalas jovens esverdeadas, 6-15×6-10 $\mathrm{mm}$; pétalas maduras alvo-amareladas, levemente avermelhadas na face adaxial, 22-30 × 7-15 mm. Estames ca. $2 \mathrm{~mm}$ compr. ápice do conectivo plano. Carpelos ca. $2 \mathrm{~mm}$ compr., na base densamente cobertos por tricomas eretos, retos; estigma nigrescente, papiloso. Frutos com receptáculo depressoobovóide; cálice não persistente; estipes in sicco nigrescentes, ca. $10 \mathrm{~mm}$ compr., glabros; carpídios in sicco nigrescentes, 27-40, ca. 10 $\times 5 \mathrm{~mm}$, elipsóides, glabros, curto apiculados. Semente vinácea, in sicco marrom claro a escuro, ca. $10 \times 5 \mathrm{~mm}$, elipsóide.

Material selecionado: Macaé, Frade, caminho para Sana, $22^{\circ} 14^{\prime} \mathrm{S} 42^{\circ} 08^{\prime} \mathrm{W}$, elev. $400 \mathrm{~m}, 19 . \mathrm{XII} .2000$, f1., $M$. G. Bovini et al. 1941 (RB); Parati, Serra da Bocaina,
Caminho do Ouro, 23.I.2001, fl., A. Q. Lobão \& $P$. Fiaschi 542 (RB, SPF); Rio de Janeiro, Parque Nacional da Tijuca, Estrada das Paineiras, 7.XI.1999, fl. e fr., $A$. Q. Lobão 446 (RB, SPF); Teresópolis, Parque Nacional da Serra dos Órgãos, parte superior da trilha do Rancho Frio, 13.II.2005, fl., J. Wesenberg 550 (RB).

Guatteria glabrescens caracteriza-se pelos ramos adultos, pecíolos, folhas, pedicelo do fruto e estipes geralmente glabros ou glabrescentes, base da lâmina foliar frequientemente decurrente e pétalas com ápice obtuso. Todas as caracteristicas que diferem G. salicifolia de G. glabrescens (Fries 1939) se enquandram na variação observada em G. glabrescens e por isso foram sinonimizadas. Guatteria glabrescens é semelhante a $G$. australis A.St.-Hil. que, no entanto, tem folhas menores e com base aguda.

Guatteria glabrescens ocorre em florestas de terras baixas e submontanas, próximo a rios ou locais úmidos, do Paraná à Bahia. Na cidade do Rio de Janeiro é freqüente no Parque Nacional da Tijuca. Foi coletada em flor de outubro a julho e em fruto de abril a dezembro. Em geral, apresenta flores e frutos simultaneamente no mesmo ramo. Em Lobão 542, cujas flores recendem a banana madura, foi observado besouro da família Nitidulidae, grupo citado como polinizador de Guatteria (Gottsberger 1988; Webber 1996).

6. Guatteria latifolia (Mart.) R.E.Fr., Acta Horti Berg. 12(3): 326, fig. 4a. 1939. Guatteria nigrescens var. latifolia Mart. in Mart. \& Eichler, Fl. bras. 13(1): 31. 1841. Typus: BRASIL. RIO DE JANEIRO: Rio de Janeiro, Serra do Tinguá, s.d., fr., H. W. Schott 5938 (holotypus, BR n.v.).

Fig. 4 a-c Árvores 4-0 m alt. Tricomas áureoferrugíneos, 0,5-1 mm compr. Gemas, folhas jovens e ramos jovens densamente cobertos por tricomas adpressos, retos; ramos adultos glabrescentes. Pecíolo nigrescente, 5-8 mm compr., profundamente canaliculado, com fissuras transversais, coberto por tricomas adpressos, retos. Lâmina foliar verde, in sicco marrom a atrofusca, 10-17(-19) ×4-6,5(-7) cm, cartácea, estreitamente elíptica a elíptica, glabra na face adaxial, glabra a esparsamente coberta por tricomas adpressos, retos, na abaxial; base aguda a cuneada; margem às vezes ondulada; 

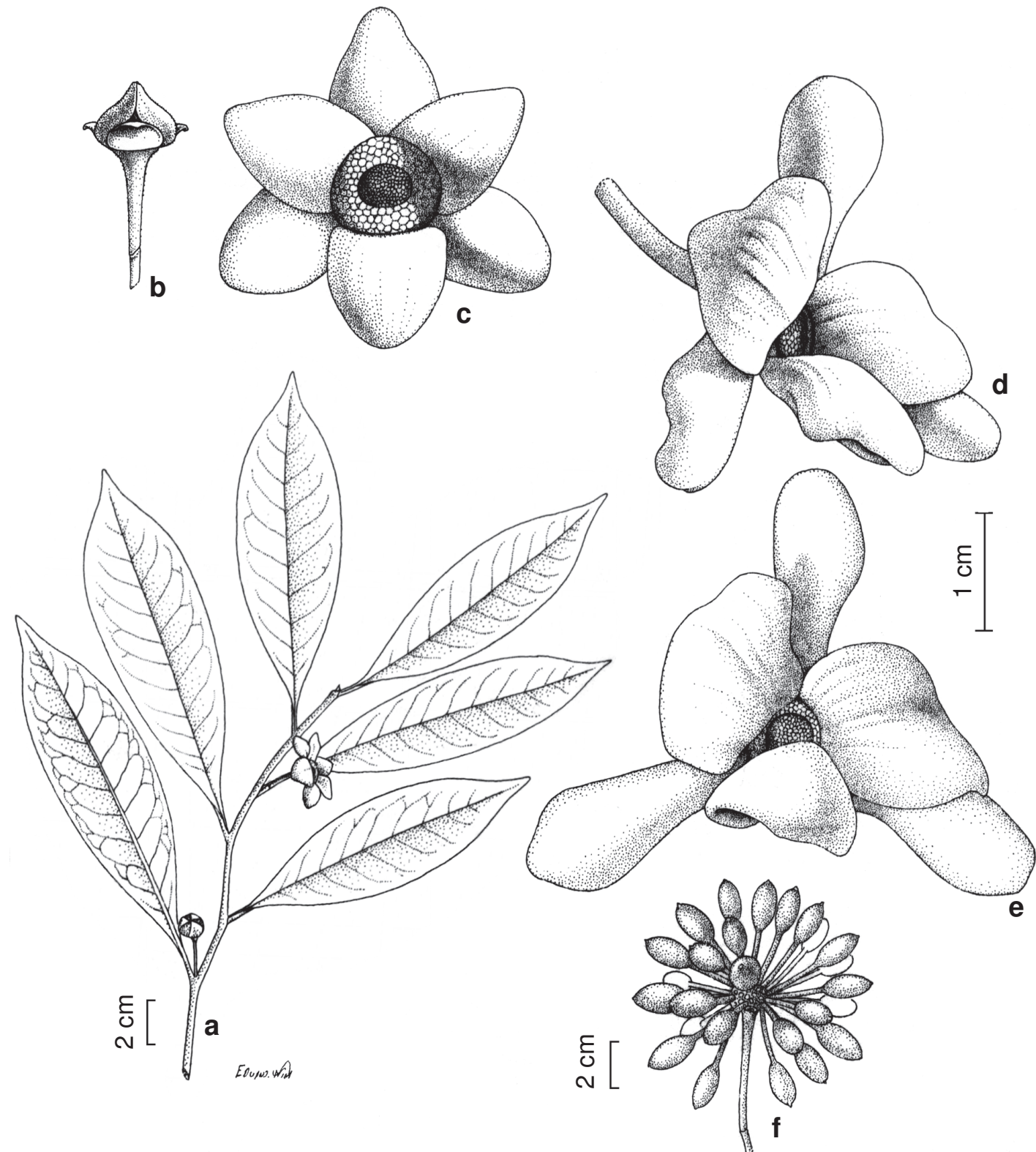

Figura 3 - a-f. Guatteria glabrescens - a. ramo com botão e flor jovem; b. botão floral; c. flor jovem; d-e. flor madura; f. fruto. (Lobão 542)

ápice acuminado, acúmen 1-2 cm compr.; nervura primária glabra a esparsamente coberta por tricomas adpressos, retos, em ambas as faces; nervuras secundárias 13-16 pares, proeminentes em ambas as faces, formando ângulo de 60-70 com a nervura primária. Flor 1, axilar. Pedicelo levemente nigrescente, 2,5-4,5(-6) cm compr., da base à articulação $0,5-2(-2,5) \mathrm{cm}$ compr., esparsamente coberto por tricomas adpressos, retos. Brácteas 2 por flor, caducas. Botões florais ca. $10 \times 12 \mathrm{~mm}$; triangular-obovóides, glabros a esparsamente cobertos por tricomas adpressos, retos, com sépalas conatas em toda a extensão, sem linha de deiscência. Sépalas verdes, in sicco nigrescentes, conatas na base, reflexas, 10-20× $10 \mathrm{~mm}$, cobertas por tricomas eretos, sinuosos, em ambas as faces, margem plana. Pétalas estreitamente elípticas, coberta por tricomas eretos, sinuosos, em ambas as faces, ápice acuminado; pétalas jovens esverdeadas, 15- 
$20 \times 6 \mathrm{~mm}$; pétalas maduras alvo-amareladas, 32 $35 \times 16-20 \mathrm{~mm}$. Estames ca. $2 \mathrm{~mm}$ compr., ápice do conectivo plano. Carpelos ca. $2 \mathrm{~mm}$ compr., base densamente coberta por tricomas eretos, retos; estigma papiloso. Frutos com receptáculo 8-10×15-17 mm, largamente depresso-obovóide; cálice às vezes persistente; estipes vináceos, in sicco nigrescentes, 2-3 cm compr., com fissuras longitudinais, glabros; carpídios vináceos, in sicco nigrescentes, 9-15 ×7 mm, elipsóides, curtoapiculados. Semente vinácea, in sicco marrom, ca. 1 cm compr., elipsóide.

Material selecionado: Itatiaia, Parque Nacional do Itatiaia, 22.I.1987, fl. e fr., R. Mello-Silva et al. 1 (NY, RB, SPF); Nova Friburgo, Roadside between Nova Friburgo and Serra Macaé, elev. 1000 m, 18.X.1977, fr., J. P. M. Maas 3324 (RB); Nova Iguaçu, Reserva Biológica do Tinguá, Estrada do Ouro, riacho Nova Estrela, $\mathrm{km} 9$ da sede da Reserva (Administração), 22³4'10"S 4328'06"W, elev. 790-800m, 13.XI.2001, fl., H. C. Lima et al 5912 (RB); Resende, Parque Nacional de Itatiaia, Maromba, 5.III.1947, fl. efr., P. Occhioni s.n. (RFA4207).

Guatteria latifolia caracteriza-se pelos botões florais grandes, com sépalas conatas em toda a extensão e receptáculo do fruto com 8 a $10 \mathrm{~mm}$ compr. e 15 a 17 mm diâm. É semelhante a G. nigrescens, cujas diferenças mais marcantes são as dimensões do botão floral e do receptáculo, e a prefloração das sépalas.

Guatteria latifolia é endêmica de Itatiaia, Resende, Nova Friburgo, Nova Iguaçu e Rio de Janeiro. É bastante freqüente no Parque Nacional de Itatiaia, onde ocorre em orla de floresta e ao longo de rios. A floração e frutificação, que são intensas, coincidem com a época mais quente e chuvosa do ano, de setembro a julho, e de setembro a abril, respectivamente. As flores em antese exalam forte odor de acetona (Lobão 455).

7. Guatteria mexiae R.E.Fr., Acta Horti Berg. 12(3): 344. 1939. Typus: BRASIL. MINAS GERAIS: Carangola, fazenda da Gramma, about $0,5 \mathrm{~km}$ North on trail, capoeira near small stream, elev. 900 m, 27.I.1930, fl., Y. E. J. Mexia 4249 (holotypus, $\mathrm{S}$ n.v.; isotypi, BM, F n.v., K, U, US n.v.; foto, SPF).

Fig. 4 d-f

Árvores ca. $4 \mathrm{~m}$ alt. Tricomas áureoferrugíneos, 0,6-0,8 mm compr. Gemas, folhas jovens e ramos jovens e adultos densamente cobertos por tricomas adpressos, retos. Pecíolo nigrescente, 3-4 mm compr., levemente canaliculado, com fissuras transversais, densamente coberto por tricomas eretos, retos. Lâmina foliar verde, in sicco marrom, 5,5-9,5 $\times 2-3,5 \mathrm{~cm}$, cartácea a levemente coriácea, estreitamente elíptica, glabra a esparsamente coberta por tricomas adpressos, retos, na face adaxial; densamente coberta por tricomas eretos, retos, na abaxial; base aguda; margem às vezes levemente revoluta; ápice agudo; nervura primária esparsamente coberta por tricomas eretos, retos, na face adaxial, densamente coberta por tricomas eretos, retos, na abaxial; nervuras secundárias ca. 13 pares, proeminentes em ambas as faces, formando ângulo de $60-70^{\circ} \mathrm{com}$ a nervura primária. Flor 1, axilar. Pedicelo $3-$ $4,5(-5) \mathrm{cm}$ compr., da base à articulação 1$1,5 \mathrm{~cm}$ compr., com fissuras longitudinais, densamente coberto por tricomas eretos, retos. Brácteas $1-4$ por flor, $1-2 \times 0,5-1 \mathrm{~cm}$, persistentes, glabras a esparsamente cobertas por tricomas eretos, retos, na face adaxial, densamente cobertas por tricomas eretos, retos, na abaxial. Botões florais triangular-ovóides, densamente cobertos por tricomas eretos, sinuosos, freqüentemente com sépalas livres, raramente conatas em toda extensão quando jovem. Sépalas verdes, in sicco nigrescentes, 6-9 $65 \mathrm{~mm}$, triangulares, livres, levemente imbricadas, eretas, cobertas por tricomas eretos, sinuosos, em ambas as faces, margem plana. Pétalas estreitamente elípticas, glabra na base da face adaxial, cobertas por tricomas eretos, sinuosos, na face abaxial, ápice obtuso; pétalas jovens esverdeadas, 9-15 $\times 5 \mathrm{~mm}$; pétalas maduras amareladas, $17-22 \times$ 7-10 mm. Estames ca. 1,5 mm compr., ápice do conectivo plano. Carpelos ca. 2 mm compr., cobertos por tricomas eretos, retos, na base; estigma papiloso. Frutos com receptáculo $10 \times$ 5-7 mm, largamente depresso-obovado; cálice não persistente; estipes com base verde, ápice vináceo, in sicco nigrescentes, 9-15 mm compr., esparsamente cobertas por tricomas eretos, retos; carpídios vináceo-escuros, in sicco nigrescentes, ca. 20,10 ×5-7 mm, elipsóides, esparsamente cobertos por tricomas adpressos; apículos 1-2 mm 


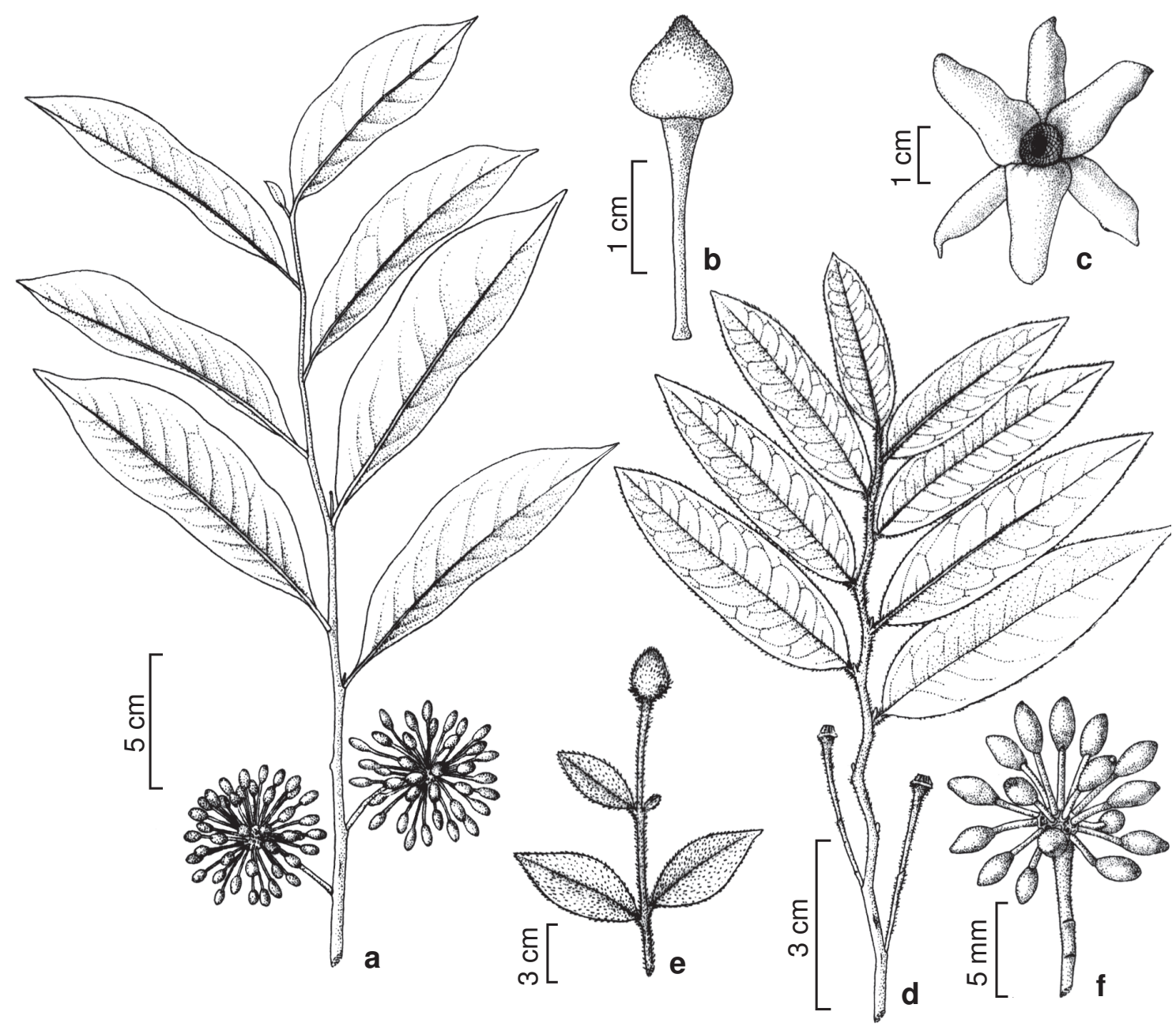

Figura 4 -a-c. Guatteria latifolia - a. ramo com frutos; b. botão floral; c. flor jovem. d-f. G. mexiae - d. ramo com resto de flor evidenciando o pedicelo; e. botão com brácteas persistentes; f. fruto. (a Brade 18826; b Maas 3324; c Lobão 455)

compr., retos ou levemente curvados. Semente in sicco marrom, ca. $1 \mathrm{~cm}$ compr., elipsóides. Material selecionado: Itatiaia, Parque Nacional de Itatiaia, Lago Azul, próximo da estrada, elev. 650700 m, 14.II.1995, J. M. A. Braga 1974 (RB); Petrópolis, Araras, Estrada do Capoeirão, elev. ca. 900 m, 26.IX.1977, fr., G. Martinelli 3008 (RB); Resende, Visconde de Mauá, Vale das Flores, na beira do Rio das Flores, 3.III.2001, fr., A. Q. Lobão 557 (RB, SPF).

Guatteria mexiae caracteriza-se pelas folhas levemente coriáceas, com face abaxial densamente coberta por tricomas e pedicelos longos, de 3 a $5 \mathrm{~cm}$ compr., densamente cobertos por tricomas. Alguns materiais (Góes 542 e 1050, Mexia 4249, Lobão 557) exibem botões florais jovens com sépalas conatas, com linha de deiscência. Assemelha-se a G. sellowiana Schltdl. queé bastante freqüente em Minas Gerais. Como única possível diferença, G. sellowiana tem pedicelo floral e frutífero raramente pouco maiores que $2 \mathrm{~cm}$ compr. enquanto que em G. mexiae essas estruturas vão de 2,5 a 5 $\mathrm{cm}$ compr., a maioria próxima ao limite superior.

Guatteria mexiae ocorre em populações esparsas, preferencialmente em floresta submontana, na Zona da Mata de Minas Gerais e na região de Petrópolis, Resende e Itatiaia no Rio de Janeiro, onde ocorrem em simpatria com G. latifolia. Foi coletada em flor em janeiro a abril, setembro a dezembro e em fruto em janeiro a março e setembro. 
8. Guatteria nigrescens Mart. in Mart. \& Eichler, Fl. bras. 13(1): 31. 1841. Typus: BRASIL. SÃO PAULO: Lorena, 1817, fl., C. F. P. Martius s.n. (holotypus, $\mathrm{M}$ n.v., isotypus, B n.v.; foto, SPF).

Fig. 5 a-f

Guatteria nigrescens var. oblongifolia Mart. in Mart \& Eichler. Fl. bras. 13(1): 31. 1841. Guatteria klotzschiana Mart. in Mart. \& Eichler, Fl. bras. 13(1): 31. 1841. Typus: BRASIL. RIO DE JANEIRO: Rio de Janeiro, Prope Tocaja, s.d., fl., A. C. V. Schott s.n. (holotypus, BR n.v.; prováveis isotypi, B n.v., $\mathrm{BR}$ n.v., S n.v., US n.v.; foto, U). Syn. nov.

Guatteria acutipetala R.E.Fr., Acta Horti Berg. 12(3): 324, tab. 13. 1939. Typus: BRASIL. RIO DE JANEIRO: Teresópolis, am Waldrande, I.1897, fl., E. H. G. Ule 3962 (holotypus, B n.v.; isotypus, K, R). Syn. nov.

Guatteria silvatica R.E.Fr., Acta Horti Berg. 12(3): 330. 1939. Typus: BRASIL. RIO DE JANEIRO: Cantagalo, 1857, fl., T. Peckolt 151 (holotypus, BR n.v.; foto, SPF). Syn. nov.

Árvores $2,5-10 \mathrm{~m}$ alt. Tricomas áureoferrugíneos, 0,6-1,2 mm compr. Gemas, folhas jovens e ramos jovens cobertos por tricomas adpressos, retos; ramos adultos glabros. Pecíolo 3-9(-14) mm compr., leve a profundamente canaliculado, espessado, com fissuras transversais, densamente coberto por tricomas adpressos, retos. Lâmina foliar verde escura, in sicco marrom a levemente atrofusca na face adaxial; verdeclara, in sicco marrom a levemente atrofuscas na adaxial, 10-19,5 $(-21) \times 3,5-7 \mathrm{~cm}$, cartácea, estreitamente elíptica a elíptica ou estreitamente obovada, glabra na face adaxial e esparsa a densamente coberta por tricomas adpressos, retos, na abaxial; base aguda a obtusa; margem plana, in sicco às vezes levemente ondulada; ápice longo-acuminado, acúmen ca. $1,5 \mathrm{~cm}$ compr.; nervura primária glabra a esparsamente coberta por tricomas adpressos, retos, na face adaxial, densamente coberta por tricomas adpressos, retos, na abaxial; nervuras secundárias ca. 15 pares, fortemente impressas na face adaxial, proeminentes na abaxial, formando ângulo de 60 $70^{\circ}$ com a nervura primária. Flores $1-2$, axilares. Pedicelo 4-5 (-6,5) cm compr., da base à articulação 7-15 mm compr., delgado, coberto por tricomas adpressos, retos, 4-7,5 cm compr. no fruto.
Brácteas 2 por flor, caducas. Botões florais 5-6 $\times 6 \mathrm{~mm}$, triangular-ovóides, esparsamente cobertos por tricomas eretos, sinuosos, com sépalas livres, valvares, reflexas. Sépalas verdes, in sicco nigrescentes, ca. 4-6 $66 \mathrm{~mm}$, largamente triangulares, livres, levemente imbricadas, reflexas, cobertas por tricomas eretos, sinuosos, na base da face adaxial, glabras na abaxial, margem plana. Pétalas estreitamente elípticas, glabras na face adaxial, densamente cobertas por tricomas eretos, sinuosos, na abaxial, ápice acuminado; pétalas jovens esverdeadas, $12-17 \times 7-8 \mathrm{~mm}$; pétalas maduras amarelas levemente avermelhadas na face adaxial, $20-30 \times 12-20 \mathrm{~mm}$. Estames ca. $2 \mathrm{~mm}$ compr., ápice do conectivo plano. Carpelos nigrescentes, ca. 2,5 mm compr., densamente cobertos por tricomas eretos, retos, na base; estigma papiloso. Frutos com receptáculo 4-5x $7 \mathrm{~mm}$, largamente depresso-obovóide; cálice não persistente; estipes vináceos, in sicco nigrescentes, 15-25 mm compr., glabros; carpídios vinho escuro, in sicco nigrescentes, ca. $10 \times 7 \mathrm{~mm}$, elipsóides, esparsamente cobertos por tricomas adpressos, curto-apiculados. Semente alaranjada, in sicco marrom claro a escuro, ca. $10 \times 5 \mathrm{~mm}$, elipsóide. Material selecionado: Angra dos Reis, Ilha Grande, Reserva Biológica Estadual da Praia do Sul, Praia do Sul,2310'S 4417'W, 19.XII.1984,fl.efr.,D. S.D.Araujo 5490 (GUA, U); Carapebus, Parque Nacional da Restinga de Jurubatiba, 13-17.VIII.2001, fl., B. Kurtzet al. 294 (RB); Mangaratiba, Reserva Rio das Pedras, Trilha do Cambucá, elev. 200-300 m, 19.X.1996, fr., $M$. G. Bovini et al. 1085 (RB, USU); Nova Friburgo, Alto Macahé, 18.I.1881, fl., A. F. M. Glaziou 17462 (paratypus de G. acutipetala, B n.v., C n.v., K, P, R); Parati, Área de Proteção Ambiental de Cairuçu, km 206 da estrada Rio-Santos, lado direito do sítio Canela Amarela, 17.X.1990, fl. e fr., V.L.G. Klein 923(RB); Rio de Janeiro, Floresta da Tijuca, s.d., fl. e fr., A. F. M. Glaziou 8253 (paratypus de G. acutipetala, B n.v., C n.v., K, P); Santa Maria Madalena, Parque Estadual do Desengano, Pedra do Desengano, 26.III.2002, st., $A$. Q. Lobão et al. 675 (RB, SPF).

Guatteria nigrescens caracteriza-se pelas folhas grandes, de $10 \mathrm{a} 19 \mathrm{~cm}$ compr. por 3,5 a $7 \mathrm{~cm}$ larg., folhas e ramos jovens densamente cobertos por tricomas, glabrescentes, pedicelo floral de 4 a $5 \mathrm{~cm}$ compr. e o frutífero de 4 a $7,5 \mathrm{~cm}$ compr. e ápice das pétalas agudo. É bastante variável na forma e dimensão dos carpídios e do 


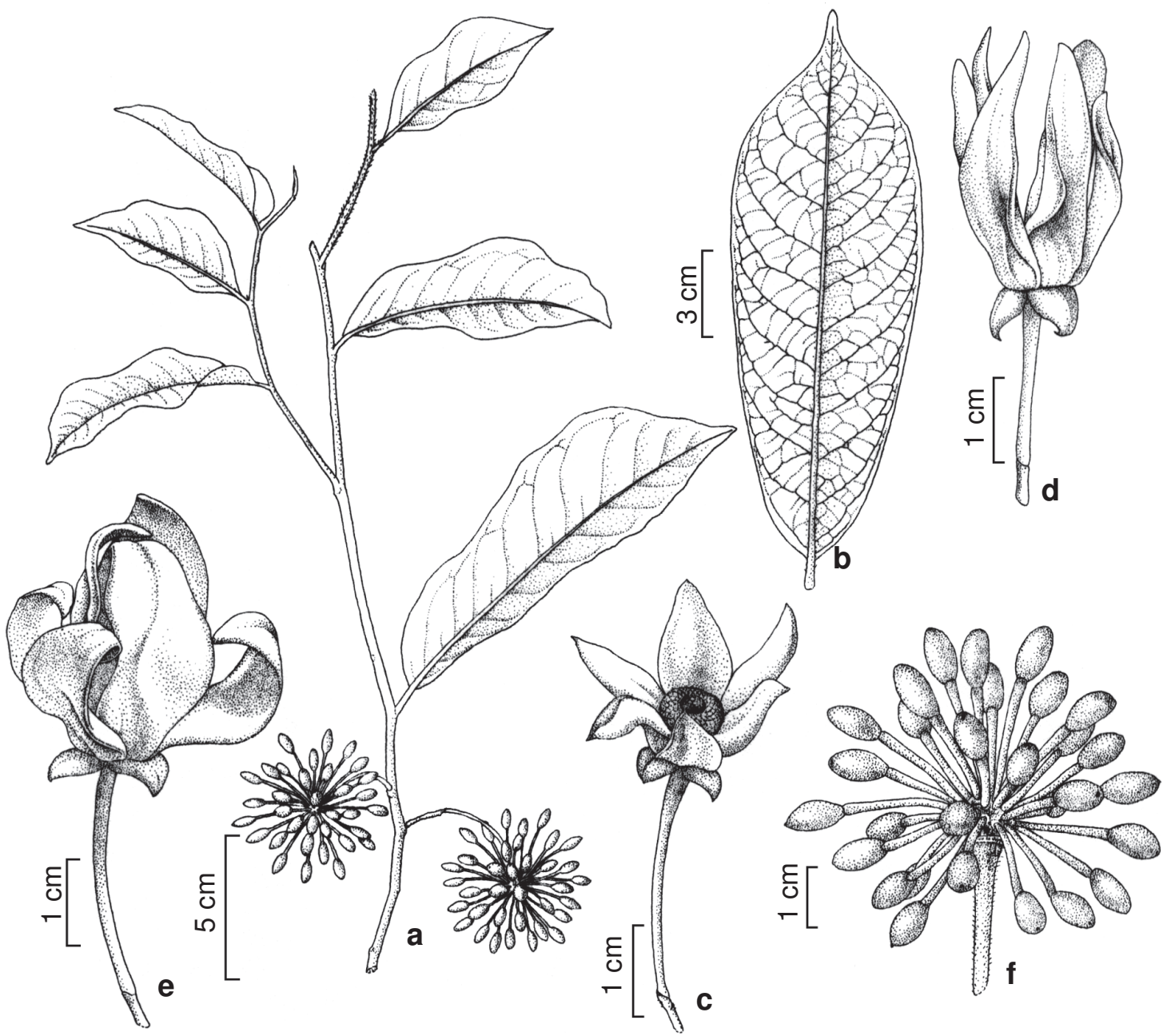

Figura 5 - a-f. Guatteria nigrescens - a. ramo com frutos; b. folha evidenciando nervuras; c. flor jovem; d-e. flores maduras; f. fruto. (a-b Farney 2591; c Kurtz 204; d Lobão 530; e Lobão 499; f Lobão 544).

pedicelo do fruto. Fries (1939) não comenta sobre as afinidades de G. acutipetala, mas os parátipos desta espécie (Glaziou 8253, 15824 e 17462) são bastante semelhantes aos materiais de $G$. nigrescens, justificando sua sinonimização. Martius (1841) define G. klotzschiana por características que se encontram dentro da variação de $G$. nigrescens e não sustentam as duas espécies. Fries (1939) distingue G. nigrescens de G. silvatica pelas sépalas menores desta última, de cerca de 4 $\mathrm{mm}$ compr. Este caráter varia em $G$. nigrescens com o estado de maturação da flor. Assim, o reconhecimento de G. silvatica como espécie é pouco consistente. Guatteria nigrescens assemelha-se a $G$. candolleana e a G. latifolia (vide comentários sobre estas espécies).
Guatteria nigrescens distribui-se na mata secundária de terras baixas e na floresta submontana, freqüentemente associada a cursos de rios ou locais alagados, na Zona da Mata de Minas Gerais até Ouro Preto, na região costeira de São Paulo e Rio de Janeiro, onde é bastante comum, e chega a Santa Maria Madalena. Foi coletada com flores de agosto a junho e com frutos de agosto a maio. Apresenta grande floração e frutificação, comumente no mesmo indivíduo. Coleóptero da família Nitidulidae, polinizadora de Guatteria (Gottsberger 1988; Webber 1996), foi encontrado em uma flor madura, a exalar forte odor de acetona. Os frutos bem maduros são saborosos (Lobão 530), sendo provavelmente alimento da avifauna. 
9. Guatteria pohliana Schltdl., Linnaea 9: 321. 1835. Typus: BRASIL. MINAS GERAIS: Sem localidade, s.d., fl. e fr., F. Sellow s.n. (holotypus, B n.v.; prováveis isotypi, K, P). Fig. 6 a-d

Arbustos ou árvores $1,5-10 \mathrm{~m}$ alt. Tricomas ferrugíneos, 0,8-1 mm compr. Gemas pequenas, ca. $5 \mathrm{~mm}$ compr., densamente cobertas por tricomas eretos, retos; ramos jovens freqüentemente flexuosos, esparsa a densamente cobertos por tricomas eretos, retos; ramos adultos glabros a esparsamente cobertos por tricomas eretos, retos; folhas jovens densamente cobertas por tricomas adpressos, retos. Pecíolo nigrescente, 3-5 mm compr., canaliculado, com fissuras transversais, esparsamente coberto por tricomas eretos, retos. Lâmina foliar verde, in sicco freqüentemente atrofuscas, 4,5-10(-12) × 1,5-2,5(-3,5) cm, cartácea, estreitamente elíptica a elíptica, glabra na face adaxial; esparsamente coberta por tricomas eretos ou adpressos, retos, na abaxial; base aguda; margem às vezes ondulada; ápice agudo; nervura primária densamente coberta por tricomas eretos, retos, em ambas as faces; nervuras secundárias proeminentes em ambas as faces, formando ângulo de $55-70^{\circ}$ com a nervura primária. Flor 1, axilar. Pedicelo in sicco nigrescente, $1,8-2,5(3) \mathrm{cm}$ compr., da base à articulação 3-7 mm compr., com fissuras longitudinais, esparsamente coberto por tricomas eretos, retos. Brácteas 2 por flor, caducas. Botões florais in sicco nigrescentes, ca. $5 \times 7 \mathrm{~mm}$, triangular-ovóides, glabros a esparsamente cobertos por tricomas adpressos, retos; com sépalas conatas em toda a extensão, sem linha de deiscência. Sépalas verdes, in sicco nigrescentes, 6-7 $\times 4-6 \mathrm{~mm}$, triangulares, livres, valvares, reflexas, glabras na face adaxial, margem plana. Pétalas ovadas, cobertas por tricomas eretos, sinuosos, em ambas as faces, ápice obtuso; pétalas jovens verdes, 6-17(-20) $\times$ 4-7 mm; pétalas maduras amarelas, $17-20 \times$ 8-10 mm. Estames ca. 1,5 mm compr., ápice do conectivo plano. Carpelos in sicco nigrescentes, ca. $1,5 \mathrm{~mm}$ compr., densamente cobertos por tricomas eretos, retos; estigma papiloso. Frutos com receptáculo ca. $6 \times 6 \mathrm{~mm}$, largamente depresso-obovóide; cálice não persistente, estipes ca. $5 \mathrm{~mm}$ compr., glabros a esparsamente cobertos por tricomas adpressos; carpídios in sicco nigrescentes, 20-30, 8-10 × $6 \mathrm{~mm}$, elipsóides, glabros a esparsamente cobertos por tricomas adpressos. Semente vinácea, in sicco marrom-avermelhada, ca. $10 \times 6 \mathrm{~mm}$, elipsóide. Material selecionado: Itatiaia, Parque Nacional de Itatiaia, Macieiras, estrada para o abrigo Macieiras, mirante, 3.XII.1997, fl., J. M. A. Braga 4505 (RB); Nova Friburgo, Macaé de Cima, Reserva Ecológica Municipal de Macaé de Cima, 6.III.1989, fl. efr., M. Peron 777 (RB, U); Parati, Morro do Cuscuzeiro, Área de Proteção Ambiental Cairuçu, elev. ca. 1250 m, 28.III.1995, fl., L. C. Giordano et al. 1855 (RB, SPF); Petrópolis, Santo Antônio, 24.IX.1875, fl., A. F. M. Glaziou 8254 (P); São José do Vale do Rio Preto, Primeiro Distrito, fazenda Serra do Capim, $22^{\circ} 19^{\prime} 48^{\prime \prime} \mathrm{S} 42^{\circ} 52^{\prime} 32^{\prime \prime} \mathrm{W}$, elev. $990 \mathrm{~m}$, 13.IX.2000, fl., F. M. B. Pereira 45/32 (RFA).

Guatteria pohliana caracteriza-se pelas folhas pequenas, de cerca de 4,5 a $10 \mathrm{~cm}$ compr., freqüentemente glabras em ambas as faces, e pelo botão floral com sépalas negras, glabras, conatas em toda a extensão e sem linha de deiscência (Fries 1939). É semelhante a $G$ pubens, mas esta última tem lâmina foliar densamente coberta por tricomas na face abaxial e sépalas livres no botão floral.

Guatteria pohliana tem ocorrência esporádica em serras do centro do Rio de Janeiro, Bahia e Minas Gerais, chegando ao Caparaó. No Rio de Janeiro, é encontrada na floresta submontana e montana. Foi coletada com flores em agosto a março e com frutos de setembro a março.

10. Guatteria pubens (Mart.) R.E.Fr., Acta Horti Berg. 12(3): 455, fig. 21a-b. 1939.

Fig. 6 e-h

Guatteria australis var. pubens Mart. in Mart \& Eichler, Fl. bras. 13(1): 26. 1841. Typus: BRASIL. RIODE JANEIRO: Petrópolis, ad rivulum prope praedium Mandioca, VIIIX.1817, fl., C. F. P. Martius s.n. (holotypus, $\mathrm{M} n . v$, foto SPF).

Guatteria umbrosa R.E.Fr., Acta Horti Berg. 12(3): 455, tab. 31. 1939. Typus: BRASIL. RIO DE JANEIRO: Petrópolis, Mandioca, X.1823, fr., L. Riedel s.n. (holotypus, S n.v.; isotypi, LE n.v., U). Syn. nov.

Árvores 4-9 m alt. Tricomas áureoferrugíneos, 0,2-0,5 mm compr. Gemas, folhas jovens e ramos jovens densamente cobertos 


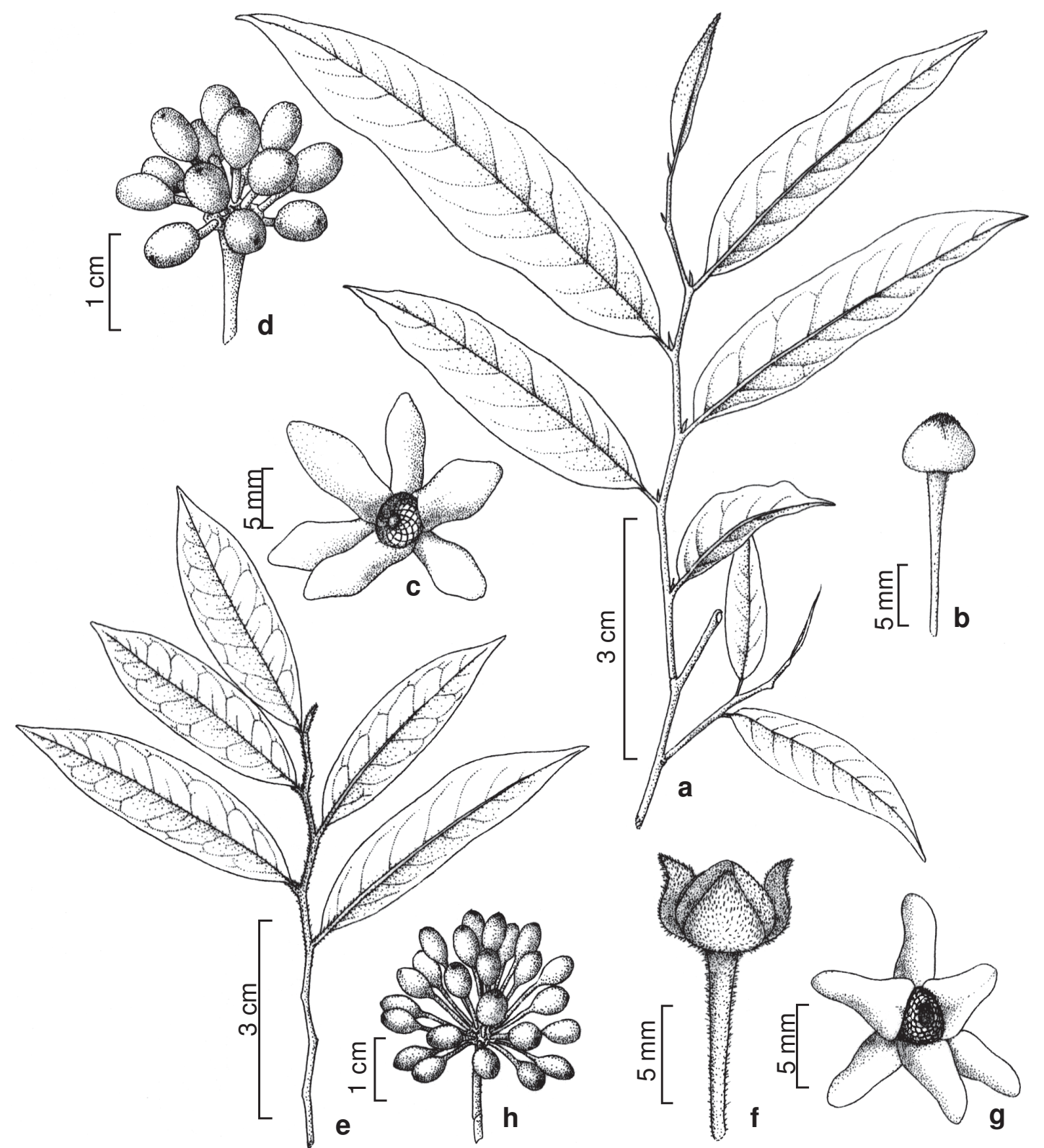

Figura 6 - a-d. Guatteria pohliana - a. ramo; b. botão com sépalas conatas sem linha de deiscência; c. flor jovem; d. fruto. e-h. G. pubens - e. ramo; f. botão com sépalas livres; g. flor jovem; h. fruto. (a, c-d Kawasaki 1066; b Pereira 45/32; e Occhioni 7867, f Simmonis 22; g Occhioni 8391; h Occhioni 7937).

por tricomas adpressos, retos; ramos jovens rígidos; ramos adultos esparsa a densamente cobertos por tricomas adpressos, retos. Pecíolo nigrescente, 2-5 $\mathrm{mm}$ compr., levemente canaliculado, com fissuras transversais, densamente coberto por tricomas adpressos, retos. Lâmina foliar verde, in sicco marrom, 5,5-10× 1,5-2,5 cm, cartácea, estreitamente elíptica a elíptica, glabra na face adaxial; densamente coberta por tricomas adpressos, retos, na abaxial; base aguda; margem plana; ápice agudo a curto acuminado, acúmem 5-7 mm compr.; nervura primária densamente coberta por tricomas adpressos, retos, em ambas as faces; nervuras secundárias 8-10 pares, proeminentes em ambas as faces, formando ângulo de $50-70^{\circ}$ com a nervura primária. Flor 1, axilar. Pedicelo nigrescente, 1$2,5 \mathrm{~cm}$ compr., da base à articulação $0,3-1 \mathrm{~mm}$ 
compr., esparsa a densamente coberto por tricomas eretos, retos. Brácteas 2 por flor, caducas. Botões florais triangular-ovóides, densamente cobertos por tricomas eretos, sinuosos; com sépalas livres, valvares, eretas. Sépalas in sicco nigrescentes, 3-5 × 3-4 mm, largamente triangular-ovadas, livres, valvares, eretas, cobertas por tricomas eretos, sinuosos na face abaxial, glabras na adaxial, margem plana. Pétalas elípticas, cobertas por tricomas eretos, sinuosos, em ambas as faces, ápice obtuso a agudo; pétalas jovens esverdeadas, 7-13 $\times$ 4-5 mm; pétalas maduras alvo-amareladas, 13$14 \times 5-6 \mathrm{~mm}$. Estames ca. 1,5 mm compr., ápice do conectivo plano. Carpelos nigrescente, ca. $2 \mathrm{~mm}$ compr., densamente cobertos por tricomas eretos, retos, na base; estigma papiloso. Frutos com receptáculo obovóide; cálice não persistente, estipes in sicco nigrescentes, ca. $1 \mathrm{~cm}$ compr., esparsamente cobertos por tricomas adpressos; carpídios in sicco nigrescentes, 24-32, ca. 8 $\times 5 \mathrm{~mm}$, elipsóides, esparsamente cobertos por tricomas adpressos, retos, curto apiculados. Semente in sicco marrom-escuro, ca. $8 \mathrm{~mm}$ compr., elipsóide.

Material selecionado: Cachoeiras de Macacu, Reserva Estadual Ecológica de Paraíso, próximo a represa da CEDAE, $22^{\circ} \mathrm{S} 42^{\circ} 03^{\prime} \mathrm{W}$, 18.II.1992, fl., $H$. C. Lima et al. 4368 (RB); Macaé, estrada Frade/Tapera, $5,3 \mathrm{~km}$ de Frade, $22^{\circ} 13,01^{\prime} \mathrm{S} 42^{\circ} 05,42^{\prime} \mathrm{W}$, elev. $509 \mathrm{~m}$, 4.III.2004, fl., R. C. Forzza et al. 2862 (RB, K); Magé, Vale das Pedrinhas, 20.IX.1975, fl. e fr., P. Occhioni 7740 (RFA, SPF); Nova Friburgo, Flor das Andorinhas, $22^{\circ} 21^{\prime} 61^{\prime}$ 'S $42^{\circ} 21^{\prime} 71$ ' W, elev. $650 \mathrm{~m}$, 17.III.2001, fl., A. Quinet 25/81 (RFA); Nova Iguaçu, Reserva Biológica do Tinguá, $150 \mathrm{~m}$ após caixa coletora de Reunião, 22`35' 17"S 43²5'28"W, 24.I.2004, fl., $H$. C. Lima et al. 6406 (K, MBM, RB, UEC); Petrópolis, Serra dos Orgãos, Morro do Cuca, elev. 1100 m, 27.I.1983, fl. e fr., J. E. Simonis \& G. Martinelli 22 (K, U); Sapucaia, Terceiro Distrito, fazenda Selo Verde, 224'55"S 4250’W, elev. 849 m, 13.V.2000, fl., F. M. B. Pereira 91/011 (RFA); Teresópolis, Venda Nova, fragmento da propriedade do Sr. Waldemar, $22^{\circ} 17^{\prime} 20^{\prime \prime S}$ $42^{\circ} 52^{\prime} 24^{\prime \prime W ~ e ~} 22^{\circ} 17 ’ 27 " \mathrm{~S} 42^{\circ} 52^{\prime} 25^{\prime \prime W}$, elev. $850 \mathrm{~m}$, 6.IX.2005, fl., C. H. R. Paula 853 (RB).

Guatteria pubens caracteriza-se por folhas pequenas com 5,5 a $10 \mathrm{~cm}$ compr. por 1,5 a $2,5 \mathrm{~cm}$ larg., face abaxial densamente coberta por tricomas, sépalas livres, até $5 \mathrm{~mm}$ compr. e pétalas com, no máximo, $14 \mathrm{~mm}$ compr. $G$. umbrosa estaria associada a $G$. pubens por seus tricomas curtos e esparsos, mas distinguir-se-iam principalmente pelo hábito (Fries 1939). Além disso, G. umbrosa caracterizar-se-ia pelas folhas e frutos pequenos. Todas estas características são comuns a $G$. pubens e os materiais-tipo das duas espécies são muito semelhantes. Guatteria pubens assemelha-se a $G$. pohliana (vide comentários em G. pohliana).

Guatteria pubens é esporádica e ocorre na floresta submontana de Cachoeiras de Macacu, Macaé, Nova Iguaçu, Serra dos Órgãos e da Tijuca, nas florestas da baixada fluminense e na zona da Mata de Minas Gerais. Foi coletada com flores de janeiro a maio, julho a novembro e com frutos em setembro, outubro e janeiro. As flores e os frutos apresentam aroma suave (Pereira 91/011).

11. Guatteria reflexa R.E.Fr., Acta Horti Berg. 12(3): 329. 1939. Typus: BRASIL. RIO DE JANEIRO: Niterói, Morro da Viração, 28.XII.1870, fl., A. F. M. Glaziou 5725 (holotypus, $\mathrm{S} n . v$; isotypi, B n.v., C n.v., F n.v., K, P, R, $\mathrm{RB}$; foto, SPF, U).

Fig. 7 a-b

Árvores. Tricomas áureo-ferrugíneos a raramente áureos, 0,2-0,5 mm compr. Gemas e folhas jovens esparsamente cobertas por tricomas adpressos; ramos jovens fortemente flexuosos, esparsamente cobertos por tricomas adpressos, retos; ramos adultos glabros. Pecíolo nigrescente, 4-5 mm compr., profundamente canaliculado, com fissuras transversais, esparsamente coberto por tricomas adpressos, retos. Lâmina foliar verde, in sicco levemente azulada a marrom, 7,5-12(-16) × 3-4 cm, coriácea, estreitamente elíptica a elíptica, glabra e brilhantes na face adaxial, esparsamente coberta por tricomas na abaxial; base aguda a levemente obtusa; margem freqüentemente revoluta; ápice agudo; nervura primária coberta por tricomas adpressos, retos, em ambas as faces; nervuras secundárias 12-15 pares, proeminentes em ambas as faces, formando ângulo de 65-80 com a nervura primária. Flor 1 , axilar. Pedicelo nigrescente, 2-3 cm compr., da base à articulação 6-10 mm compr., com fissuras longitudinais, glabro, raro densamente coberto por tricomas eretos, retos. 


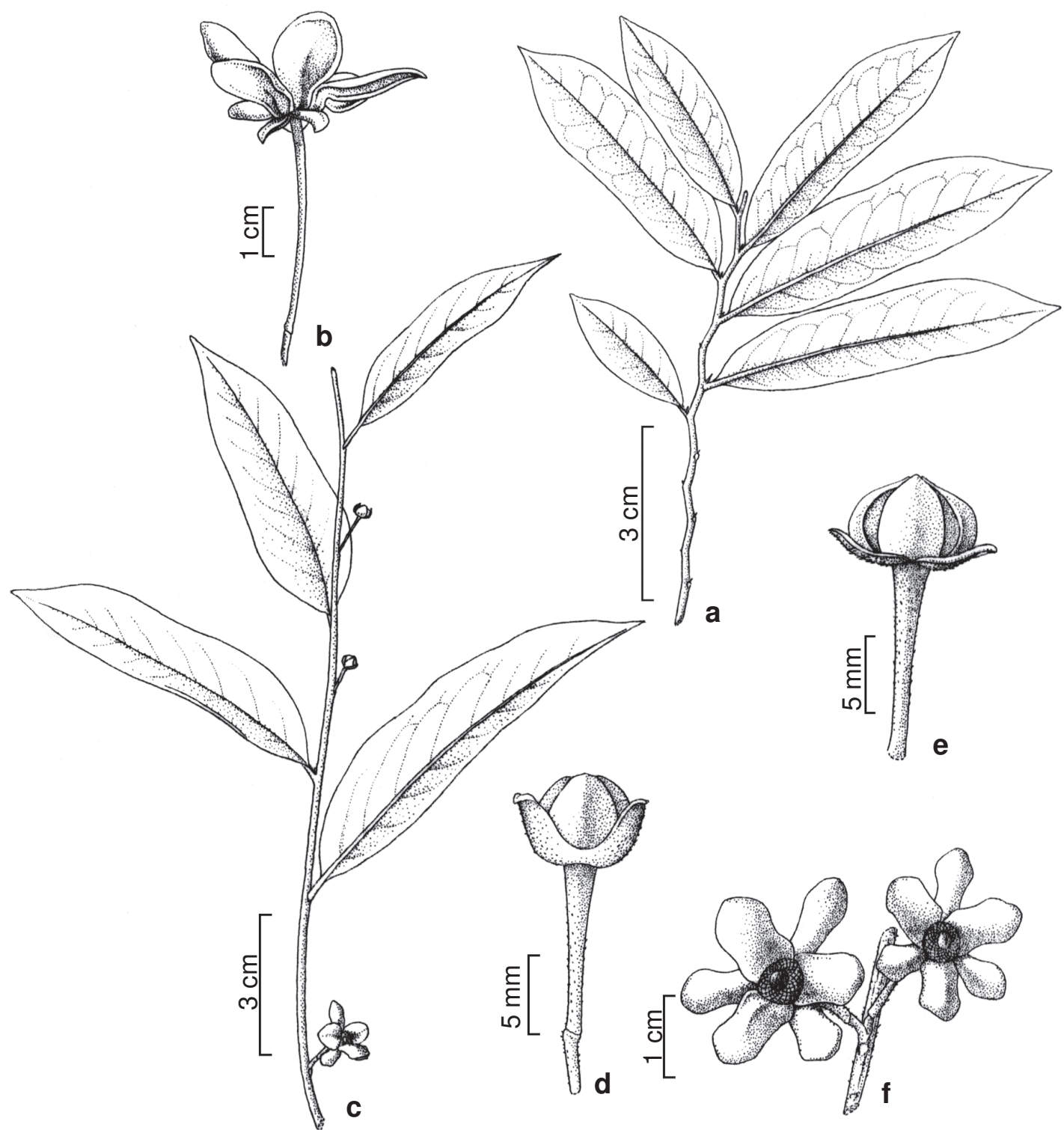

Figura 7 - a-b. Guatteria reflexa a. ramo; b. vista dorsal de flor jovem. c-f. G. xylopioides - c. ramo com botões florais e flor jovem; d. botão floral com sépalas conatas na metade proximal; e. botão floral com sépalas conatas na base; f. inflorescência biflora. (a.b Glaziou 3858; c-e Oliveira 474B; f Oliveira 474N).

Brácteas às vezes persistentes, $5-10 \mathrm{~mm}$ compr. Botões florais triangular-ovóides, $5-8 \times 7-10 \mathrm{~mm}$, com sépalas livres, valvares. Sépalas in sicco nigrescentes, ca. $4 \times 4 \mathrm{~mm}$, livres, triangulares, valvares, reflexas, cobertas por tricomas eretos, sinuosos, na face abaxial, margem plana. Pétalas ovadas, densamente cobertas por tricomas adpressos, retos, na face adaxial, esparsamente cobertas por tricomas eretos, sinuosos, no ápice e glabras na base, ápice agudo; pétalas jovens esverdeadas, $10-16 \times 6-9 \mathrm{~mm}$; pétalas maduras amareladas, $16-18 \times 5-10 \mathrm{~mm}$. Estames ca. $2 \mathrm{~mm}$ compr., ápice do conectivo plano. Carpelos ca. $3 \mathrm{~mm}$ compr., na base densamente cobertos por tricomas eretos, retos, áureos; estigma papiloso, nigrescente. Frutos não vistos. Material selecionado: Rio de Janeiro, Parque Nacional da Tijuca, Represa dos Ciganos, elev. 200300 m, 30.IX.1977, fr., G. Martinelli 3181 (RB); Niterói, Engenho do Mato, Parque Estadual da Serra da Tiririca, Morro do Telégrafo, Trilha da Barreira, 22.I.2005, fl., A. A. M. Barros 2423 (RB, RFFP). 
Guatteria reflexa caracteriza-se pelos ramos jovens fortemente flexuosos, folhas com pecíolo curto, de 4-5 mm compr., lâminas coriáceas, brilhantes e com face adaxial glabra, margem in sicco freqüentemente revoluta, pedicelo delgado, com cerca de $2-3 \mathrm{~cm}$ compr., e carpelos com cerca de $3 \mathrm{~mm}$ compr. Assemelha-se a G. klotzschiana (Fries 1939) aqui sinonimizada em G. nigrescens. Entretanto, o tipo de G. klotzschiana possui pecíolo de 5 a $8 \mathrm{~mm}$ compr., folhas com 10 a $20 \mathrm{~cm}$ compr. com base longamente aguda. Guatteria reflexa foi coletada em 1869, 1870, 107 anos depois, em 1977 e, em 2005, em sua localidade-tipo. Não há coleções com frutos.

Guatteria reflexa é endêmica da Baía da Guanabara, onde ocorre em floresta submontana. Foi coletada com flor em dezembro e em fruto em setembro.

12. Guatteria villosissima A.St.-Hil., Fl. Bras. merid. 1: 38. 1825. Typus: BRASIL. MINAS GERAIS: Rio Piracicaba, Serra dos Pilões près Itajuru de São Miguel de Mato Dentro, III.1817, fl., A. F. C. P. Saint-Hilaire 606 (holotypus, $\mathrm{P}$; isotypus, $\mathrm{P}$ ). $\quad$ Fig. 8 a-e Guatteria villosissima var. longepedunculata R.E.Fr., Acta Horti Berg. 12(3): 351. 1939. Typus: BRASIL. RIO DE JANEIRO: Nova Friburgo, II.1903, fl., $P$. $K$. H. Dusén 1910 (holotypus, S n.v.; isotypus, U). Syn. nov.

Árvores 3-8 m alt. Tricomas ferrugíneos, $0,8-1 \mathrm{~mm}$ compr. Gemas, ramos adultos e folhas jovens densamente cobertos por tricomas eretos, retos; ramos jovens rígidos, densamente cobertos por tricomas eretos, retos. Pecíolo nigrescente, 1-3 mm compr., canaliculado, densamente coberto por tricomas eretos, retos. Lâmina foliar verde, in sicco verde a marrom, 6,5-15 $(-18) \times 1,5-3(-4,5) \mathrm{cm}$, coriácea a cartácea, estreitamente elíptica a elíptica, esparsamente coberta por tricomas eretos, retos, na face adaxial; densamente coberta por tricomas eretos, retos, na abaxial; base obtusa; margem in sicco freqüentemente revoluta; ápice agudo; nervura primária densamente coberta por tricomas eretos, retos, em ambas as faces; nervuras secundárias ca. 13 pares, proeminentes em ambas as faces, formando ângulo de 55-60 com a nervura primária. Flor 1, axilar. Pedicelo nigrescente, $1,5-2(-3,5) \mathrm{cm}$ compr., da base à articulação 0,5-1,2 cm compr., densamente coberto por tricomas eretos, retos. Brácteas 2 por flor, caducas. Botões florais triangular-ovóides, densamente cobertos por tricomas eretos, retos; com sépalas conatas em toda extensão, com linha de deiscência. Sépalas ferrugíneas, 8-10 $\times 7 \mathrm{~mm}$, largamente triangulares, livres, valvares, eretas, glabras na base da face adaxial, margem revoluta. Pétalas ovadas a elípticas, densamente cobertas por tricomas, adpressos, sinuosos, ápice agudo; pétalas jovens esverdeadas, 6-17(20)×4-7 mm; pétalas maduras amarelas, nigrescentes na base da face adaxial, 17-25 $\times$ 5-12 mm. Estames ca. 1,5 mm compr. ápice do conectivo plano. Carpelos nigrescentes, ca. 1,5 mm compr., densamente cobertos por tricomas eretos, retos; estigma papiloso. Frutos com receptáculo largamente depressoobovoide; cálice não persistente, estipes ca. 3 mm compr., cobertos por tricomas adpressos, retos; carpídios in sicco nigrescentes, ca. $8 \times$ $6 \mathrm{~mm}$, elipsóides, glabros a esparsamente cobertos por tricomas adpressos, retos; apiculados, apículos às vezes laterais. Semente in sicco marrom, ca. $8 \mathrm{~mm}$ compr., elipsóide. Material selecionado: Nova Friburgo, Cascata do Pinel, 18.IV.1987, fl., J. C. Siqueira 2217 (FCAB); São José do Vale do Rio Preto, $1^{\circ}$ Distrito, fazenda do Capim, $22^{\circ} 28^{\prime} \mathrm{S} 42^{\circ} 52^{\prime} \mathrm{W}$, elev. $813 \mathrm{~m}$, 17.VII.2000, fl., F.M. B. Pereira 37/021 (RFA); Santa Maria Madalena, subida para a Pedra do Desengano, 21 $1^{\circ} 52,31^{\prime} \mathrm{S} 41^{\circ} 55,58^{\prime} \mathrm{W}$, elev. 822 m; 2.III.2004, fl., R. C. Forzza et al. 2830 (RB, SPF); Sapucaia, $3^{\circ}$ Distrito, $22^{\circ} 24^{\prime} \mathrm{S} 42^{\circ} 50^{\prime} \mathrm{W}$, elev. 767 m, 26.I.2001, fr., F. M. B. Pereira 11/68 (RFA); Teresópolis, Venda Nova, Vale das Palmeiras, fragmento II, $22^{\circ} 17^{\prime} 13^{\prime \prime S} 42^{\circ} 53^{\prime} 22^{\prime \prime} \mathrm{W}$, elev. 900m, 28.V.2005, fl., C. H. R. Paula 787 (RB); Sem localidade definida, s.d., fl., A. F. M. Glaziou 2922 (P).

Material adicional: MINAS GERAIS: Belo Horizonte, Estação Ecológica da Universidade Federal de Minas Gerais, 13.IV.1992, fl., L. V. Costa s.n. (BHCB 22386, SPF); Congonhas do Norte, Serra da Carapina (Serra Talhada na folha do IBGE), setor $\mathrm{N}$ da Serra do Cipó, $18^{\circ} 53^{\prime} \mathrm{S} 43^{\circ} 43^{\prime} \mathrm{W}$, elev. ca. 1250 m, 11.I.1998, fl., J. R. Pirani et al. 4249 (K, MBM, 


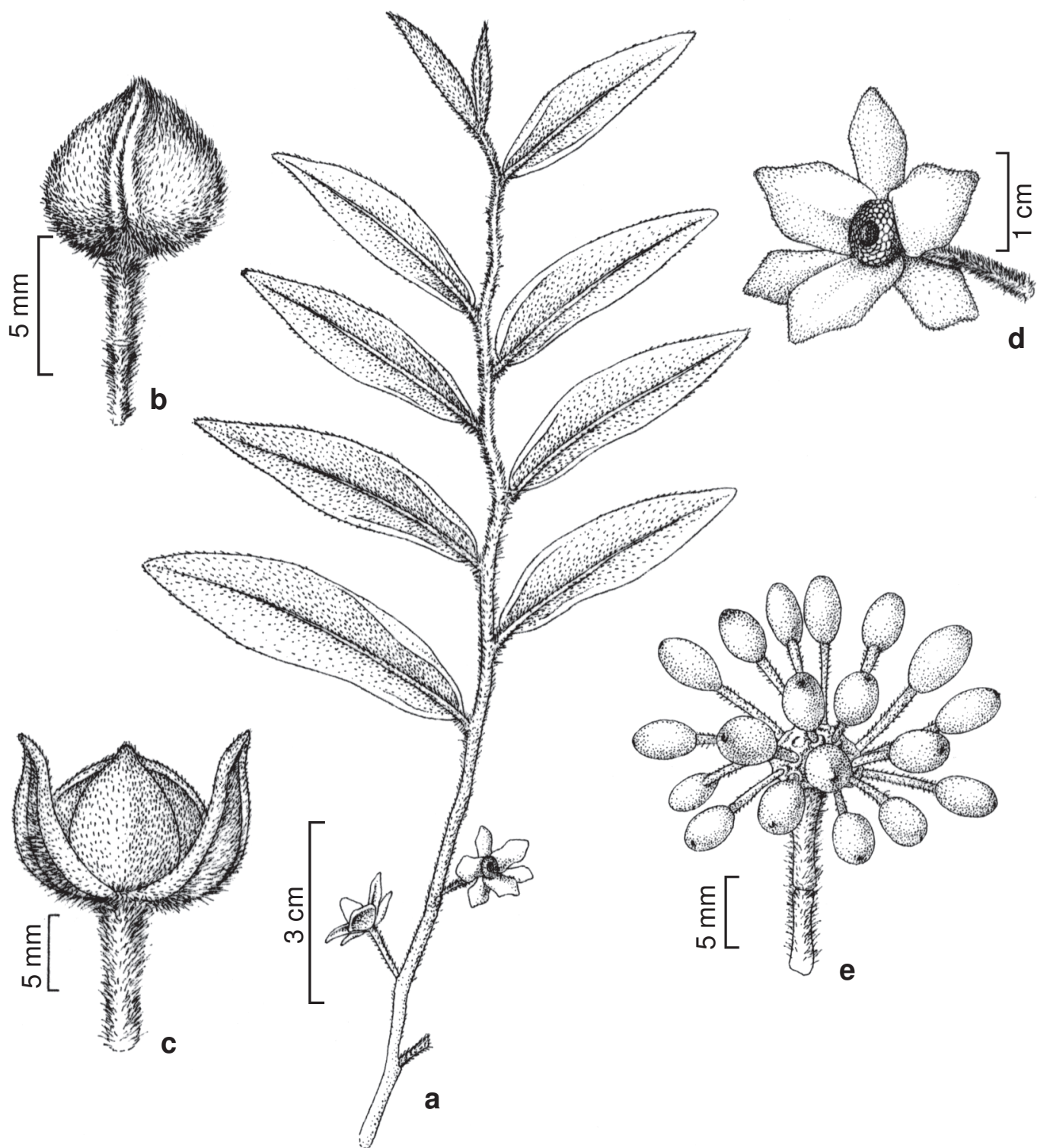

Figura 8 - a-e. Guatteria villosissima - a. ramo; b. botão floral jovem; c. botão floral maduro; d. flor jovem; e. fruto. (a Siqueira 2217; b Marcondes-Ferreira 276; c-d Pirani 4249; e Lopes s.n. (VIC 17068)).

MO n.v., SPF); Nova Lima, Reserva Biológica Mata do Jambeiro, 29.X.1990, fr., P. M. Andrade 1346(BHCB, $\mathrm{SPF})$; Serro, estrada de terra em frente à placa divisa Pres. Kubitscheke Serro, 18`34'17'S 4333'55”'W, elev. 1270m, 10.VII.2001, fl.,A. Q. Lobão etal. 630(RB, SPF).

Guatteria villosissima caracteriza-se pelas folhas coriáceas a cartáceas, quase sésseis, esparsamente cobertas por tricomas na face adaxial e densamente na abaxial, margem in sicco freqüentemente revoluta, pedicelo curto, de 1,5 a 2,3 cm compr., densamente coberto por tricomas e botões florais jovens com sépalas conatas em toda a extensão, com linha de deiscência. É uma espécie bem definida morfologicamente. Guatteria villosissima var. longepedunculata diferenciar-se-ia da variedade típica pelas folhas com até $20 \mathrm{~cm}$ compr. e pedicelo com cerca de $3 \mathrm{~cm}$ compr. (Fries 1939). Pedicelos deste comprimento podem ser observados em diversas coleções de G. villosissima (e.g. Andrade 1346, Costa BHCB 22386, Lobão 630, Pirani 4249) não classificáveis na variedade longepedunculata por não compartilharem as 
dimensões das folhas desta variedade. O tipo da variedade longepedunculata, mesmo que apresentando folhas um pouco maiores que o observado entre as populações do Rio de Janeiro, não deve ser reconhecido como um táxon à parte visto que alguns materiais de G. villosissima possuem folhas com até $18 \mathrm{~cm}$ compr. O material-tipo de G. villosissima var. longepedunculata representa apenas um extremo da espécie quanto a este caráter.

Guatteria villosissima ocorre preferencialmente em floresta úmida, mas também em capoeiras, em Minas Gerais, onde é frequiente, no Espírito Santo e no Rio de Janeiro, onde há apenas uma coleção de cada um dos cinco municípios de ocorrência. Foi coletada em flor em todos os meses do ano e em fruto em outubro a janeiro.

13. Guatteria xylopioides R.E.Fr., Acta Horti Berg. 12(3): 459, fig. 21g. 1939. Typus: BRASIL. RIO DE JANEIRO: Cabo Frio, II.1882, fl., $A$. F. M. Glaziou 13401 (holotypus, B n.v.; isotypi, K, P; foto, SPF).

Fig. 7 c-f

Árvores ca. $6 \mathrm{~m}$ alt. Tricomas áureoferrugíneos, 0,6-1,2 mm compr. Gemas cobertas por tricomas adpressos; ramos jovens rígidos, cobertos por tricomas adpressos, retos; ramos adultos glabros, com fissuras transversais; folhas jovens não vistas. Pecíolo 5-10 mm compr., canaliculado, com fissuras transversais, in sicco freqüentemente retorcido, glabro a esparsamente coberto por tricomas adpressos, retos. Lâmina foliar verde, in sicco marrom, 10-17×3-6 cm, cartácea, estreitamente elíptica, glabra na face adaxial; esparsamente coberta por tricomas adpressos, retos, na abaxial; base aguda; margem plana, ápice agudo; nervura primária glabra na face adaxial, esparsamente coberta por tricomas adpressos, retos, na abaxial, bastante proeminente na fase abaxial; nervuras secundárias ca. 13 pares, impressas na face adaxial, bastante proeminentes na abaxial, formando ângulo de 40-55 com a nervura primária. Flores 1-2, axilares. Pedicelo 1-1,7 cm compr., da base à articulação 4-7 mm compr., com fissuras transversais, esparsamente coberto por tricomas eretos, sinuosos. Brácteas 2 por flor, caducas. Botões florais triangular-ovóides, densamente cobertos por tricomas adpressos, retos, com sépalas conatas na metade proximal. Sépalas in sicco nigrescentes, ca. $6 \times 6 \mathrm{~mm}$, largamente triangulares, livres, valvares, reflexas, cobertas por tricomas eretos, sinuosos, na face adaxial, glabras na abaxial, margem plana. Pétalas ovadas, glabras na base da face adaxial, densamente cobertas por tricomas eretos, sinuosos, na abaxial, ápice obtuso; pétalas jovens esverdeadas, $12-15 \times 6 \mathrm{~mm}$; pétalas maduras amareladas, 20-23 ×7 mm. Estames ca. $1 \mathrm{~mm}$ compr., ápice do conectivo plano. Carpelos nigrescentes, ca. $2 \mathrm{~mm}$ compr., densamente cobertos por tricomas eretos, retos, na base; estigma papiloso. Frutos não vistos.

Material selecionado: Nova Friburgo, Rio das Flores, fazenda Santa Genoveva, elev. 500-600 m, 7.X.1971, fl., D. Sucre 7775 (RB, SPF); Rio das Ostras, Reserva Biológica União, 15.VIII.1997, fl., P. P. Oliveira 474A (BHCB); Silva Jardim, Reserva Biológica de Poço das Antas, $22^{\circ} 30^{\prime} / 22^{\circ} 33^{\prime} \mathrm{S} 42^{\circ} 15^{\prime} / 42^{\circ} 19^{\prime} \mathrm{W}$, trilha para a fazenda Portuense, próximo à entrada do Cajueiro, 28.XI.1992, fl., H. C. Lima 4540 (RB).

Guatteria xylopioides caracteriza-se pelas folhas estreitamente elípticas, semelhantes às de algumas Xylopia (daí o epíteto específico), pela nervura primária muito proeminente na face abaxial, nervuras secundárias impressas na face adaxial, muito proeminentes na abaxial, pedicelo de 1 a 1,7 cm compr., uma a duas flores axilares e sépalas pequenas, com cerca de $6 \times$ $6 \mathrm{~mm}$, em geral conatas na metade proximal. Os materiais de Rio das Ostras e Silva Jardim apresentam folhas e flores maiores que as do isótipo em K. Entretanto, as características restantes são semelhantes. No isótipo em $\mathrm{P}$, a face abaxial da lâmina foliar é esparsamente coberta por tricomas curtos e eretos, retos, e os botões florais têm sépalas livres, diferentemente da maioria do material analisado. É semelhante a G. sellowiana, da qual se diferenciaria pelas folhas mais estreitas, lanceoladas e longas, tricomas mais curtos e rígidos, sépalas glabras na face adaxial e pétalas mais longas (Fries 1939). Assemelha-se também a G. nigrescens, mas esta geralmente possui flores solitárias, folhas elípticas ou estreitamente obovadas e ápice das pétalas agudo. 
Guatteria xylopioides é endêmica de Cabo Frio, Rio das Ostras e Silva Jardim, em floresta de terras baixas, e de Nova Friburgo, em floresta submontana. Foi coletada somente com flores, de agosto a março.

\section{Agradecimentos}

Adriana Q. Lobão agradece à Fundação Botânica Margareth Mee pela bolsa para visita aos herbários $\mathrm{K}, \mathrm{P}$ e U e principalmente ao Prof. Dr. Paul Maas por toda ajuda. Renato de Mello-Silva agradece à Margareth Mee Amazonian Trust pela bolsa para estudos de Annonaceae nos herbários BR, K, OXF, P e U, e ao herbário K pela confecção dos cibracromos dos tipos de Guatteria de K e P e seu envio ao herbário SPF. Os autores agradecem a Eduardo Kickhofel pelas ilustrações. Adriana Q. Lobão foi bolsista de mestrado da FAPESP e Renato de Mello-Silva é bolsista de produtividade do CNPq.

\section{REFERÊNCIAS BIBLIOGRÁFICAS}

Amorim, A. M. A. 2003. Estudos taxonômicos em Heteropterys (Malpighiaceae). Tese de Doutorado. Universidade de São Paulo, São Paulo.

APGII (Angiosperm Phylogeny Group). 2003. An update of the Angiosperm Phylogeny Group classification for the orders and families of flowering plants: APG II. Botanical Journal of the Linnean Society 141: 399-436.

Barringer, K. 1984. A new species of Guatteria (Annonaceae) from Panama. Annals of the Missouri Botanical Garden 71: 1186-1187.

Barroso, G. M.; Guimarães, E. F.; Ichaso, C. L. F.; Costa, C. G. \& Peixoto, A. L. 1978. Sistemática de angiospermas do Brasil. V.1. LTC/EDUSP, São Paulo, 255p.

; Morim, M. P.; Peixoto, A. L. \& Ichaso, C. L. F. 1999. Frutos e sementes: morfologia aplicada à sistemática de dicotiledôneas. Ed. Universidade Federal de Viçosa, Viçosa, 443p.

Chatrou, L. W.; Rainer, H. \& Maas, P. J. M. 2004. Annonaceae (Soursop Family). In: Smith, N.; Mori, S. A.; Henderson, A.; Stevenson, D. W. \& Heald, S. V. (eds.). Flowering Plants of the Neotropics. The
New York Botanical Garden, New York. Pp. 18-20.

CIDE (Centro de Informações e Dados do Estado do Rio de Janeiro). 1995. Anuário estatístico do estado do Rio de Janeiro. 1993/94. Vol. 11-12. SECPLAN-RJ, Rio de Janeiro.

Cronquist, A. 1981. An integrated system of classification of flowering plants. Columbia University Press, New York, 1262p.

Doyle, J. A. \& Le Thomas, A. 1996. Phylogenetic analysis and character evolution in Annonaceae. Bulletin du Muséum National d'Histoire Naturelle. Section B, Adansonia 4(18): 279-334.

Erkens, R. H. J. 2007. From morphological nightmare to molecular conundrum. Phylogenetic, evolutionary and taxonomic studies on Guatteria (Annonaceae). $\mathrm{PhD}$ Thesis. University of Utrecht, Utrecht. ; Maas, P. J. M.; Chatrou, L. W.; Schatz, G. E. \& Zamora, N. 2006. Seven taxonomic discoveries in Annonaceae from South-eastern Central America. Blumea 51(2): 119-220.

Font Quer, P. 1965. Diccionario de Botánica. Ed. Labor, Barcelona.

Fries, R. E. 1939. Revision der Arten einiger Anonaceen-Gattungen V. Acta Horti Bergiani 12(3): 289-540, taf. 1-40.

Gottsberger, G. 1988. The reprodutive biology of primitive angiosperms. Taxon 37(3): 630-643.

He, P.; Koek-Noorman, J. \& Maas, P. J. M. 1999. Studies in Annonaceae: XXXV. Phylogeny of the Guatteria-group and related genera. Acta Botanica Yunnanica 21(3): 269-286.

Heusden, E. C. H. 1992. Flowers of Annonaceae: Morphology, classification, and evolution. Blumea 7: 1-218.

Holmgren, P. K.; Holmgren, N. H. \& Barnett, L. C. 1990. Index herbariorum: Part I. The herbaria of the world. $8^{\text {th }}$ ed. The New York Botanical Garden, New York. 693p.

Maas, P. J. M.; Maas-van de Kamer, H.; Junikka, L.; Mello-Silva, R. \& Rainer, H. 2001. Annonaceae from central-eastern Brazil. Rodriguésia 52(80): 61-94. 
Martius, C. F. P. 1841. Annonaceae. In: Martius, C. F. P. \& Eichler, A. W. (eds.). Flora brasiliensis. Frid. Fleischer, Leipzig, 13: 1-63.

Pirie, M.D.; Chatrou,L.W.; Erkens, R.H.J.; Maas, J. W.; Niet, T.; Mols, J. B. \& Richardson, J. E. 2005. Phylogeny reconstruction and molecular dating in four neotropical genera of Annonaceae: the effect of taxon sampling in age estimation. Regnum Vegetabile 143: 149-174.

Radford, A. E.; Dickison, W. C.; Massey, J. R. \& Bell, C.R. 1974. Vascular plant systematics. Harper \& Row Publ, New York.

Scharf, U.; Maas, P. J. M. \& Morawetz, W. 2005. Five new species of Guatteria (Annonaceae) from the Pakaraima Mountains, Guyana. Blumea 50: 563-573.

$\&$. 2006. Five new species of Guatteria (Annonaceae) from French Guiana, Guyana and Suriname. Blumea 51: 117-130.
Schlechtendal, D. F. L. 1834. De Anonaceis brasiliensibus herbarii regii berolinensis. Linnaea 9: 315-331.

Setten, A. K. \& Koek-Noorman, J. 1992. Studies in Annonaceae XVII. Fruits and seeds of Annonaceae: morphology and its significance for classification and identification. Bibliotheca Botanica 142: 1-152.

Webber, A. C. 1996. Biologia floral, polinização e aspectos fenológicos de algumas Annonaceae na Amazônia Central. Tese de Doutorado. Instituto de Pesquisas da Amazônia e Fundação Universidade do Amazonas, Manaus.

Weberling, F. 1989. Morphology of flowers and inflorescences. Cambridge University Press, Cambridge.

Wurdack, J. J. 1970. Erroneus data in Glaziou colletions of Melastomataceae. Taxon 19(6): 911-913.

\section{LISTA DE EXSICATAS}

Albuquerque, S. Z. 5 (13)

Allemão e Cysneiro, F. F. G s.n. (2)

Almeida, A. L. 30 (2)

Almeida, V. C. 82 (10)

Amorim, A. M. A. 818 (1), 4460 (4)

Andrade, P. M. 832 (9), 1346 (12)

Angeli, C. 245 (5), 522 (5)

Araujo, D. S. D. $1365(5), 3398(4), 3410(2), 5490(8)$, $6136(2), 6490(8), 6549(8), 6580(8), 7156(9), 7293$ (8), 10407 (8), $10496(5)$

Árbocz, G. F. 553 (8)

Assis, L. C. S. 606 (8), 883 (8), 884 (8), 887 (8), 939 (8), $944(8)$

Auler, L. 1 (5)

Badini, J. OUPR 251 (9)

Barbosa, M. R. 261 (6), 286 (6), 399 (6), 472 (4)

Barros, A. A. M. 2423 (11)

Barros, W. D. 1191 (2)

Batista, E. R. 64 (8)

Bianchini, R. S. 851 (8)

Bovini, M. G. 539 (8), 552 (8), 650 (8), 894 (6), 1085 (8), 1123 (8), 1703 (4), 1941 (5), 1945 (4), 2139 (6)

Brade, A. C. 11307 (5), 12079 (1) 16780 (5), 18826 (6)
Braga, J. M. A. 1669 (6), 1697 (1), 1974 (7), 2673 (4), 2730(2), 2908(6), 4034(4), 4326(4), 4500(7), 4505(9)

Braga, P. I. S. 1903 (9)

Burchell, W. J. 1839 (2), 2014 (2), 2698 (1), 4078 (5)

Campos, D. P. 4 (8)

Carauta, J. P. P. 5441 (5), 5453 (4)

Carvalho, A. M. 661 (1), 389 (9)

Castro, R. M. 465 (8), 515 (8), 562 (10)

Catharino, E. L. M. 1979 (2)

Cavalcante, D. C. 294 (8)

Cesar, O. 78 (6), 664 (6), HRCB 1937 (6)

Chautems, A. 195 (9)

Clausen, P. 95 (12), 1089 (12), 1499 (12), Ps.n (12)

Cordeiro, I. 1935 (8)

Costa, L. V. 371 (8), T3-304 (12), BHCB 22386 (12), BHCB 52468 (2)

Cowan, R. S. 38187 (4)

Cunha Mello RB 66467 (7)

Custodio Filho, A. 1470 (8)

Custódio, T. 234 (12)

Duarte, A. P. 1510 (4), 2297 (8), 8455 (2), 8457 (12), 8469 (4), 8608 (12), 8835 (12), 9630 (12), 4975 (5)

Duarte, M. RB 65280 (1) 
Ducke, A. RB 19611 (4)

Dusén, P. K. H. 214 (2), 1910 (12), S s.n. (5)

Esteves, R. 4 (8), 24 (8)

Faria, P. C. L. CESJ 34484 (8)

Farias, D. S. 124 (4), 164 (2), 346 (13)

Farney, C. 548 (4), 1233 (2), 2591 (8)

Fiaschi, P. 731 (8)

Flaster, B. 8 (1)

Forzza, R. C. 1717 (8), 2030 (8), 2739 (4), 2830 (12), $2862(10)$

Freire-Fierro, A. 1636 (9)

Galeti, M. SPF 110297 (8)

Furlan, A. 681 (8)

Gardner, G. 306 p.p. (2)

Gentry, A. $49813(5)$

Giordano, L. C. 1782 (8), 1855 (9), 2024 (8)

Glaziou, A.F.M 1028(10), 2481 (5), 2677 (5), 2922 (12) $3855(2), 3857(2), 3858(11), 5725(11), 6856(4), 7504$ (2), 7505 (5), 7506a (2), 7508 (5), 8253 (8), 8254 (9), 9605(3), 10223(5), 11783(10), $13401(13), 13513(9)$, 14465 (9), 15824 (8), $16690(4), 17462(8), 17463(12)$ Godoy, J. R. L. 171 (8)

Góes, O. C. 46 (2), 63 (2), 123 (2), 432 (2), 542 (7), 793 (2), 1050 (7), 1069 (2)

Gomes, M. 519 (1)

Gonçalves, S. B. 257 (8)

Gottsberger, G. 13-15471 (6), 21-7774 (12)

Gottsberger, I. 11-28969 (8)

Grandi, T. S. M. 94 (12)

Guedes, M. L. 733 (9)

Guedes, R.R.68(1), 178(1);940(10),2159(2), 2173 (2), 2210(1), 2220(1),2224(1), 2280(13), 2333(6),2469(6)

Hatschbach, G. 52937 (12)

Hill, S. R. 12959 (4)

Hoehne, F. C. SP 39251 (8)

Jardim, J. G. 4460 (1)

Hoehne, W. SPF 13102 (8), SPF 15481 (8)

Kallunki, J. A. 531 (1)

Kirizawa, M. 3061 (8)

Klein, V. L. G. 923 (8), 962 (8), 1202 (8)

Konno, T. U. P. 111 (8)

Krieger, L. 23340 (9)

Kuhlmann, J. G. 48 (7), 4483 (5), RB 19664 (1), RB 81370 (5), RB 136533 (8), VIC 2127 (10)

Kuhlmann, M. 48 (7), 2676 (8)

Kurtz, B. C. 122 (4), 117 (2), 294 (8), RB 290853 (2)

Landrum, L.R. 2215 (5)

Lanna Sobrinho, J. P. 1219 (5)

Leitão Filho, H. F. 27754 (12)

Leitman, M. 383 (2)
Lima, H. C. 1551 (1), 2210 (1), 2358 (1), 3405 (2), 3561 (2), 3695 (2), 4310 (1), 4368 (10), 4540 (13), 4623 (13), 4640 (2), 5887 (1), 5912 (6), 6406(10), RB 290843 (2), RB 290852 (2)

Lima, M. P. M. 160 (6), 169 (2), 302 (6)

Lindeman, J. C. 4191 (2)

Lobão, A. Q. 444 (8), 446 (5), 447 (5), 455 (6), 490 (8), 494 (8), 497 (8), $526(8), 534(8), 542(5), 544(6), 557$ (7), $565(2), 630(12), 643(4), 645(2), 650(1), 652(8)$, 675 (8), 678 (6), 693 (8), 694 (5), 702 (2), 704 (2), 713 (2), 737 (4), 742 (4)

Lombardi, J.A. 4671 (12)

Luchiari, C. 146 (13), 319 (13), 471 (4), 696 (2)

Luciano \& Oliveira, C. A. L. 231 (5)

Luschnath, B. BR s.n. (2)

Lutz, B. 972 (2)

Maas, P. J. M. 3222 (6), 3324 (6), 7087 (5), 8816 (5);

Marcondes Ferreira,, 276 (12)

Marques, M. C. 304 (8)

Marquete, R. 162 (8), 177 (8), $272(8), 413(8), 829(8)$, $1232(8), 1759(8), 3416(6)$

Martinelli, G. 3008 (7), 3064 (2), 3181 (11), 9329 (10), 9841 (8), 10408 (1), 10560 (2), 10739 (6), 11604 (4), $11713(2), 11823(2), 12258(2), 12986(2)$

Martins, D. 103 (5)

Martius, C. F. P. B s.n. (10), M s.n. (10), M s.n. (8);

Matos, A. RB 78224 (5)

Mattos, J. 15477 (6)

Meira Neto, J. A. A. VIC 11935 (8)

Melo, E. PCD 1696 (9)

Mello Barreto, H. L. 3216 (12)

Mello, C. RB 66468 (6)

Mello-Silva, R. 1 (6), 255 (12), 1239 (8), 1334 (12), 1728 (8), 1813 (9)

Mendonça, R. R. 59 (8)

Messias, M. C. T. B. OUPR 1395 (8)

Mexia, Y.E. J. 4249 (7)

Miers, J. 7506a (2)

Moraes Pedro, L. R. 787 (8)

Morawetz, W. 31-12181 (6)

Mori, S. A. 9448 (9), 9464 (9), 12993 (1)

Motta, R. RB 61314 (6)

Moura, L. C. $23(8)$

Moura, L. S. 49 (12)

Moura, R. 157 (5)

Nadruz, M. 499 (2), 506 (2), 572 (2)

Neto, L. 201 (12)

Occhioni, P. 113 (5), 955 (2), 3874 (1), 4483 (1), 4785 (1),P. 6761 (1), 6975 (1), $6982(10), 7137$ (10), 7398 (2), $7700(2), 7740(10), 7903(1), 7937(10), 8391(10), 8667$ (4), 8766 (10), 9089 (1), RFA4207 (6), RFA4208 (2) 
Oliveira, C. A. L. 656 (8), 1583 (5), 1739 (5)

Oliveira, P.P.474(13), 474A(13), 474B (13), 474N(13)

Paula, C. H. R. 724 (2), 780 (2), 787 (12), 853 (10)

Peckolt, T. 151 (8)

Pedralli, G. EC286(12)

Pedrosa, D. S. 1133 (5)

Peixoto, A. L. 1869 (4)

Pereira, C. E. B. 59 (4)

Pereira, E. 18 (2), 454 (2), 655 (5), 2297 (4), 2383 (12), 2941(12),3831(5),4273(5),4868(2),5120(5), 10656(1)

Pereira, F. M. B. 11/68 (12), 11/74 (2), 28/44 (2), 37/ 021 (12), 45/32 (9), 91/011 (10)

Pereira, O. J. 886 (8), 1090 (12)

Peron, M. 222 (9), 243 (9), 430 (9), 497 (9), 508 (9), 767 (2), 769 (2), 777 (9), 881 (2)

Pessoa, S. V.A. 124 (2), 144 (2), 438 (2), 454 (2), 463 (2), 628 (10), 647 (13), 731 (13), RB 290840 (2)

Pessoal do Horto Florestal 80 (5), RB 62344 (5)

Pilges RB 34482 (6)

Pífano, D. 196 (8); 207 (8)

Pinheiro, F. 276 (8), 708 (8)

Pinheiro, R. S. 1354 (1), 1830 (1)

Pinto, C. G. 19 (8)

Pirani, J. R. 320 (12), 322 (12), 3946 (12), 4249 (12), 4753 (8)

Piratininga, A. 14 (13)

Porto, C. 2087 (6), 2662 (6), 2667 (6)

Quinet, A. 25/81 (10), 87 (4), 752 (6)

Ramos, W. D. 31 (6)

Ribeiro, A. G. HLCB 027458 (1)

Ribeiro, R. 967 (8), 1015 (8), 1061 (8), 1100 (8), 1108 (8), $1141(8), 1136(5), 1171(8), 1219(8), 1243(5)$, $1773(5), 2056(8), 2112(8)$

Riedel, L. 1776 (8), S s.n. (10)

Rocha, E. S. F. 1612 (5)

Rodrigues, K. 1252 (6)

Rodrigues, R. ESA 7250 (8)

Rosa, P. RB 81409 (5)

Ryland, A. 30 (1), 138 (1)

Saint-Hilaire, A. F. C. P. 2 (4), 606 (12)

Salimena, F.R. CESJ 31013 (8), CESJ 31397 (8)

Salino, A. 5906 (8)

Sampaio, A. 2362 (2), 7029 (12)

Sanches, C. D. 11 (8)

Sant'Ana, S. C. 861 (5)
Santiago, S. A. 29 (8)

Santos, N. D. 391 (1)

Santos, T. S. 1426 (1), 1726 (1), 2433 (1)

Schott, H. W. 5938 (6), BR s.n. (8)

Scheel-Ybert, R. 335 (8)

Schwacke, C. A. W. R 60957 (2)

Seele, C. 721 (5)

Sellow, F. 5442 p.p. (2), B s.n. (9)

Silva, I. M. 485 (1)

Silva, L.A. M. 3614 (1)

Silva Neto, S. J. 517 (6), 872 (6), 876 (6), 979 (4), 1484

(4), 1697 (10)

Simonis, J. E. 22 (10)

Siqueira, J. C. 2210 (2), 2217 (12)

Solza, D. S. 341 (4)

Souza, V. C. 8419 (9), 9018 (8)

Stehmann, J. R. 2279 (9)

Sucre, D. 889 (2), 2415 (2), 3476 (2), 5648 (4), 6590 (2), $7385(5), 7445(5), 7775(13), 7812$ (5), $7965(5)$, 9516(5), $10588(2), 10626(7)$

Sugiyama, M. 1043 (8)

Sylvestre, L. 840 (13), 842 (13), 1046 (6)

Tamashiro, J. Y. 1278 (8)

Tameirão Neto, E. 88 (12), 2801 (6)

Tavares, A. M. 57 (8)

Teixeira, W.A. BHCB 26132 (12)

Thomas, W. W. 13790 (5); 14107 (4)

Toledo, F. R. N. BHCB 22766 (8)

Torres, R. B. 23142 (6)

Ule, E. H. G. 2371 (2), 3962 (8), 3963 (2), 4525 (2)

Vasco RB 81526 (8)

Vasconcelos, M. F. BHCB 41460 (12)

Vattimo, I. RB 74956 (7)

Vaz, A. F. 643 (2)

Velloso, H. P. 587 (2)

Vidal, J. II-9 (2), II-47 (2), II-697 (1), II-5630 (2), II5779 (2), R 41024 (5)

Vieira, C. M. 63 (2), 240 (13), 301 (2), 908 (4)

Vitta, F.A. SPF 75606 (8)

Weir, J. K s.n. (5)

Wendt, T. 183 (2)

Wesenberg, J. 550 (5)

Zampa, P.C. CESJ 31173 (8)

Zaú, A. S. 106 (8)

Zborowski, M. 6 (8) 